\title{
Studi: Kasus Asuhan Keperawatan Jiwa Pada Tn.M Dengan Masalah Halusinasi Pendengaran Di Jl. Sipodang Kec. Sosorgadong Di Lingkungan Masyarakat
}

\author{
Rutina Pasaribu \\ Rutinapasaribu712@gmail.com
}

\section{BAB I \\ PENDAHULUAN}

\subsection{Latar Belakang}

Skizofrenia merupakan bentuk gangguan jiwa yang terdapat diseluruh dunia. Skizofrenia adalah penyakit kronis berupa gangguan mental yang serius yang ditandai dengan gangguan dalam proses pemikiran yang mempengaruhi perilaku (Thorson et al, 2008). Sekitar 45\% pasien yang dirawat di Rumah sakit jiwa merupakan pasien skizofrenia dan sebagian besar pasien skizofrenia tersebut memerlukan perawatan baik itu rawat inap dan rawat jalan dalam waktu yang lama (Gasril, P., Suryani, S., \& Sasmita, H. 2020). Menurut WHO (2019) Skizofrenia merupakan suatu gangguan jiwa berat yang bersifat berat dan kronis yang menyerang 20 juta orang di seluruh dunia. Skizofrenia merupakan penyakit kronis, parah, dan melumpuhkan, gangguan otak yang di tandai dengan pikiran kacau, waham, delusi, halusinasi, dan perilaku aneh atau katatonik (Pardede \& Laia, 2020).

Halusinasi merupakan hilangnya kemampuan manusia dalam membedakan rangsangan internal (pikiran) dan rangsangan eksternal (dunia luar). Pasien dengan halusinasi mendapatkan respon tentang lingkungannya tanpa ada objek rangsangan yang nyata. Sebagai contoh pasien mengatakan mendengar suara padahal kenyataannya tidak ada orang yang berbicara. Orang dengan gangguan kejiwaan memiliki kecenderungan menjadi penyendiri/mengisolasi diri dari dunia luar. Mereka kesulitan bersosialisasi dengan orang lain. Banyak dari mereka merasa mendengar suara / bisikan yang bisa 
mempengaruhi mereka menjadi pemarah, melakukan kekerasan, dan bahkan bisa melakukan bunuh diri. (Jatinandya, 2020)

Menurut Stuart dan Laraia (2005 dalam Muhith, 2015) klien yang mengalami halusinasi dapat kehilangan kontrol dirinya sehingga bisa membahayakan dirinya, orang lain maupun lingkungan. Klien benarbenar kehilangan kemampuan penilaian realitas terhadap lingkungan. Dalam situasi ini, klien dapat melakukan bunuh diri (suicide), membunuh orang lain (homicide), dan 
bahkan merusak lingkungan. Selain masalah yang diakibatkan oleh halusinasi biasanya juga mengalami masalah keperawatan yang menjadi penyebab (triger) munculnya halusinasi. Masalah-masalahnya antara lain harga diri rendah dan isolasi sosial. Akibat yang ditimbulkan halusinasi dapat membahayakan dirinya sendiri, orang lain, maupun lingkungan disekitarnya yang bersifat merugikan.( Pratiwi, M., \& Setiawan, H.2018).

Survey awal dilakukan di Rumah Tn. M di Jalan sipodang kec. Sosorgadong di dalam pembuatan askep ini berjumlah 1 orang dengan pasien masalah halusinasi pendengaran atas nama inisial Tn. M penyebabnya Tn. M sebagai subjek di karenakan pasien belum bisa mengatasi emosinya . Maka tujuan asuhan keperawatan yang akan di lakukan ialah untuk mengajarkan standar pelaksanaan masalah halusinasi pendengaran pada saat Tn. M mengalami halusinasinya.

\subsection{Rumusan Masalah}

Berdasarkan masalah yang telah di paparkan pada latar belakang maka rumusan masalah dalam askep ini yaitu Asuhan KeperawatanPada Tn. M Dengan Gangguan Persepsi Sensori : Halusinasi Pendengaran diMasyarakat

\subsection{Tujuan}

\subsubsection{Tujuan Umum}

Mahasiswa mampu memberikan asuhan keperawatan secara holistik dan komprehensif kepada Tn.M dengan gangguan persepsi sensori : halusinasi pendengaran.

\subsubsection{Tujuan Khusus}

1. Mahasiswa mampu melakukan pengkajian pada Tn.M dengan gangguan persepsi sensori : halusinasi pendengaran.

2. Mahasiswa mampu menegakkan diagnosa keperawatan yang ada pada Tn.M dengan gangguan persepsi sensori : halusinasi pendengaran. 
3. Mahasiswa mampu menetapkan perencanaan keperawatan pada Tn.M dengan gangguan persepsi sensori : halusinasi pendengaran.

4. Mahasiswa mampu melakukan implementasi keperawatan pada Tn.M dengan gangguan persepsi sensori : halusinasi pendengaran.

5. Mahasiswa mampu mengevaluasi hasil asuhan keperawatan pada Tn.M dengan gangguan persepsi sensori : halusinasi pendengaran.

6. Mahsiswa mampu mendokumentasikan asuhan keperawatan yang diberikan pada Tn.M dengan gangguan persepsi sensori : halusinasi pendengaran.

\subsection{Manfaat Penulisan}

1. Responden

Diharapkan tindakan yang telah di ajakarkan dapat di terapkan secara mandiri untuk mengontrol emosi dan untuk mendukung kelangsungan kesehatan klien. 


\section{BAB 2 \\ TINJAUAN TEORITIS}

\subsection{Konsep Halusinasi}

\subsubsection{Pengertian}

Halusinasi merupakan suatu penyerapan panca indera tanpa ada rangsangan dari luar, orang sehat persepsinya akurat,mampu mengidentifikasi dan menginter prestasikan stimulus berdasarkan informasi yang diterimanya melalui panca indera. Stimulus tersebut tidak ada pada pasien halusinasi. Akibat yang ditimbulkan pada pasien halusinasi dapat berakibat fatal karena beresiko tinggi untuk merugikan diri pasien sendiri, orang lain disekitarnya (Aritonang, 2021).

Halusinasi adalah salah satu gejala gangguan sensori persepsi yang dialami oleh klien gangguan jiwa, klien merasakan sensasi berupa suara, penglihatan, pengecapan, perabaan, atau penghiduan tanpa stimulus nyata. (Keliat, 2014). Halusinasi pendengaran paling sering terjadi ketika klien mendengar suara -suara, halusinasi ini sudah melebur dan klien merasa sangat ketakutan, panik dan tidak bisa membedakan antara khayalan dan kenyataan yang dialaminya (Pardede et al, 2021).

\subsubsection{Klasifikasi Halusinasi}

Menurut (Yusuf, 2015) klasifikasi halusinasi dibagi menjadi 5 yaitu :

\begin{tabular}{|c|l|cr|c|}
\hline No & \multicolumn{1}{|c|}{$\begin{array}{c}\text { Jenis } \\
\text { halusinasi }\end{array}$} & \multicolumn{2}{|c|}{ Data Objektif } & \multicolumn{2}{|c|}{ Data Subjektif } \\
\hline 1 & Halusinasi & 1. Bicara & atau & 1. Mendengar suara \\
& Pendengaran & tertawa sendiri & \multicolumn{2}{c|}{ atau kegaduhan } \\
& & tanpa lawan & 2. Mendengar suara \\
& & bicara & \multicolumn{2}{|c|}{ yang mengajak } \\
& & 2. Marah-marah & \multicolumn{2}{|c|}{ bercakap-cakap } \\
\hline
\end{tabular}




\begin{tabular}{|c|c|c|c|}
\hline & & $\begin{array}{l}\text { tanpa sebab } \\
\text { mencondongkan } \\
\text { telinga ke arah } \\
\text { tertentu } \\
\text { 3. Menutup telinga }\end{array}$ & $\begin{array}{l}\text { 3. Mendengar suara } \\
\text { yang menyuruh } \\
\text { melakukan sesuatu } \\
\text { yang berbahaya }\end{array}$ \\
\hline 2 & $\begin{array}{l}\text { Halusinasi } \\
\text { penglihatan }\end{array}$ & $\begin{array}{l}\text { 1. Menunjuk- } \\
\text { nunjuk ke arah } \\
\text { tertentu } \\
\text { 2. Ketakutan pada } \\
\text { objek yang tidak } \\
\text { jelas }\end{array}$ & $\begin{array}{l}\text { 1. Melihat bayangan, } \\
\text { sinar, bentuk } \\
\text { geometris, bentuk } \\
\text { kartun, melihat } \\
\text { hantu atau monster }\end{array}$ \\
\hline 3 & $\begin{array}{l}\text { Halusinasi } \\
\text { penghindu }\end{array}$ & $\begin{array}{l}\text { 1. Menghindu } \\
\text { seperti sedang } \\
\text { membaui bau- } \\
\text { bauan tertentu } \\
\text { 2. Menutup hidung }\end{array}$ & $\begin{array}{l}\text { 1. Membaui bau-bauan } \\
\text { seperti bau darah, } \\
\text { urine, feses, } \\
\text { 2. kadang-kadang bau } \\
\text { itu menyenangkan }\end{array}$ \\
\hline 4 & $\begin{array}{l}\text { Halusinasi } \\
\text { pengecepan }\end{array}$ & $\begin{array}{l}\text { 1. Sering meludah } \\
\text { 2. Muntah }\end{array}$ & $\begin{array}{l}\text { 1. Merasakan rasa } \\
\text { seperti darah, urine, } \\
\text { feses }\end{array}$ \\
\hline 5 & $\begin{array}{l}\text { Halusinasi } \\
\text { perabaan }\end{array}$ & $\begin{array}{l}\text { Menggaruk-garuk } \\
\text { permukaan kulit }\end{array}$ & $\begin{array}{l}\text { 1. Mengatakan ada } \\
\text { serangga di } \\
\text { permukaan kulit } \\
\text { 2. Merasa seperti } \\
\text { tersengat listrik }\end{array}$ \\
\hline
\end{tabular}

\subsubsection{Tanda dan Gejala}

Menurut Marsela \& Dirdjo (2016) tanda dan gejala halusinasi adalah:
a. Bicara, senyum sendiridan tertawa.
b. Mengatakan mendengar suara.
c. Merusak diri sendiri/orang lain/lingkungan. 
d. Tidak dapat membedakan hal yang nyata dan hal yang tidak nyata.

e. Tidak dapat memusatkan konsentrasi/perhatian.

f. Pembicaraan kacau kadang tidak masuk akal.

g. Sikap curiga dan bermusuhan.

h. Menarik diri, menghindar dari orang lain.

i. Sulit membuat keputusan.

j. Ketakutan.

k. Mudah tersinggung, jengkel, mudah marah.

1. Menyalahkan diri sendiri/orang lain.

m. Tidak mampu melaksanakan asuhan mandiri : mandi, berpakaian.

n. Muka merah kadang pucat.

o. Ekspresi wajah tegang

p. Tekanan darah meningkat meningkat.

q. Nadi cepat.

r. Banyak berkeringat.

\subsubsection{Etiologi}

Faktor predisposisi klien halusinasi menurut (Oktiviani, 2020) :

1. Faktor Predisposisi

a. Faktor perkembangan

Tugas perkembangan klien terganggu misalnya rendahnya kontrol dan kehangatan keluarga menyebabkan klien tidak mampu mandiri sejak kecil, mudah frustasi, hilang percaya diri.

b. Faktor sosiokultural

Seseorang yang merasa tidak diterima dilingkungan sejak bayi akan merasa disingkirkan, kesepian, dan tidak percaya pada lingkungan.

c. Biologis

Faktor biologis Mempunyai pengaruh terhadap terjadinya gangguan jiwa. Adanya stress yang berlebihan dialami 
seseorang maka didalam tubuh akan dihasilkan suatu zat yang dapat bersifat halusinogen neurokimia.Akibat stress berkepanjangan menyebabkan teraktivasinya neurotransmitter otak.

d. Psikologis

Tipe kepribadian lemah dan tidak bertanggung jawab mudah terjerumus pada penyalahgunaan zat adikitif. Hal ini berpengaruh pada ketidakmampuan klien dalam mengambil keputusan yang tepat demi masa depannya, klien lebih memilih kesenangan sesaat dan lari dari alam nyata menuju alam khayal.

e. Sosial Budaya

Meliputi klien mengalami interaksi sosial dalam fase awal dan comforting, klien meganggap bahwa hidup bersosialisasi di alam nyata sangat membahayakan. Klien asyik dengan Halusinasinya, seolah-olah ia merupakan tempat untuk memenuhi kebutuhan akan interaksi sosial, kontrol diri dan harga diri yang tidak didapatkan dakam dunia nyata.

\section{Faktor Presipitasi}

Faktor presipitasi merupakan stimulus yang dipersepsikan oleh individu sebagai tantangan, ancaman, atau tuntutan yang memerlukan energi ekstra untuk menghadapinya. Seperti adanya rangsangan dari lingkungan, misalnya partisipasi klien dalam kelompok, terlalu lama tidak diajak komunikasi, objek yang ada di lingkungan dan juga suasana sepi atau terisolasi, sering menjadi pencetus terjadinya halusinasi. Hal tersebut dapat meningkatkan stress dan kecemasan yang merangsang tubuh mengeluarkan zat halusinogenik. Penyebab Halusinasi dapat dilihat dari lima dimensi (Oktiviani, 2020) yaitu :

a. Dimensi fisik: Halusinasi dapat ditimbulkan oleh beberapa kondisi fisik seperti kelelahan yang luar biasa, penggunaaan obat- 
obatan, demam hingga delirium, intoksikasi alkohol dan kesulitan untuk tidur dalam waktu yang lama.

b. Dimensi Emosional: Perasaan cemas yang berlebihan atas dasar problem yang tidak dapat diatasi merupakan penyebab halusinasi itu terjadi. Isi dari halusinasi dapat berupa perintah memaksa dan menakutkan. Klien tidak sanggup lagi menentang perintah tersebut hingga dengan kondisi tersebut klien berbuat sesuatu terhadap ketakutan tersebut.

c. Dimensi Intelektual: Dalam dimensi intelektual ini menerangkan bahwa individu dengan halusinasi akan memperlihatkan adanya penurunan fungsi ego. Pada awalnya halusinasi merupakan usaha dari ego sendiri untuk melawan impuls yang menekan, namun merupakan suatu hal yang menimbulkan kewaspadaan yang dapat mengambil seluruh perhatian klien dan tidak jarang akan mengontrol semua perilaku klien.

d. Dimensi Sosial: Klien mengalami interaksi sosial dalam fase awal dan comforting, klien meganggap bahwa hidup bersosialisasi di alam nyata sangat membahayakan. Klien asyik dengan Halusinasinya, seolah-olah ia merupakan tempat untuk memenuhi kebutuhan akan interaksi sosial, kontrol diri dan harga diri yang tidak didapatkan dakam dunia nyata.

e. Dimensi Spiritual: Secara sepiritual klien Halusinasi mulai dengan kehampaan hidup, rutinitas tidak bermakna, hilangnya aktifitas ibadah dan jarang berupaya secara sepiritual untuk menyucikan diri. Saat bangun tidur klien merasa hampa dan tidak jelas tujuan hidupnya. Individu sering memaki takdir tetapi lemah dalam upaya menjemput rezeki, menyalahkan lingkungan dan 


\begin{tabular}{|c|c|c|}
\hline Adaptif & & Maladaptif \\
\hline $\begin{array}{ll}\text { - } & \text { Pikiran logis } \\
\text { - } & \text { Persepsi akurat } \\
\text { - } & \text { Emosi konsisten dengan } \\
\text { pengalaman } \\
\text { - } \\
\text { - } \text { Herilaku cocok. } \\
\text { harmonis. }\end{array}$ & $\begin{array}{l}\text { - } \text { Kadang proses pikir tidak } \\
\text { terganggu } \\
\text { - } \text { Ilusi } \\
\text { - } \text { Emosi tidak stabil } \\
\text { - } \text { Perilaku tidak biasa } \\
\text { - } \text { Menarik diri }\end{array}$ & $\begin{array}{l}\text { - } \text { Gangguan proses } \\
\text { berpikir/waham. } \\
\text { - } \text { Halusinasi. } \\
\text { - } \text { Kesukaran proses emosi. } \\
\text { - } \text { Perilaku tidak } \\
\text { terorganisasi } \\
\text { - } \text { Isolasi social }\end{array}$ \\
\hline
\end{tabular}

(Damaiyanti \& Iskandar 2014 ) menjelaskan rentang respon halusinasi sesuai bagan di atas, yakni :

1. Respon Adaptif

Respon adaptif respon yang dapat diterima oleh norma-norma sosial budaya yang berlaku. Dengan kata lain individu tersebut dalam batas normal jika menghadapi suatu masalah akan dapat memecahkan masalah tersebut, responadaftif :

a. Pikiran logis adalahpandangan yang mengarah pada kenyataan. Persepsi akurat adalah pandangan yang tepat pada kenyataan.

b. Emosi konsisten dengan pengalaman yaitu perasaan yang timbul dari pengalaman

c. Perilaku sosial adalah sikap dan tingkah laku yang masih dalam batas kewajaran.

d. Hubungan sosial adalah proses suatu interaksi dengan orang lain dan lingkungan.

2. Respon Maladaptif 
Respon maladaptif adalah respon individu dalam menyelesaikan masalah yang menyimpang dari norma-norma sosial budaya dan lingkungan, adapun respon maladaptif meliputi:

a. Kelainan pikiran adalah keyakianan yang secara kokoh dipertahankan walaupun tidak diyakini oleh orang lain dan bertetangan dengan kenyataan sosial.

b. Halusinasi merupakan persepsi sensori yang salah atau persepsi eksternal yang tidak realita atau tidak ada.

c. Kerusakan proses emosi adalah perubahan sesuatu yang timbul dari hati.

d. Perilaku tidak terorganisir merupakan suatu yang tidak teratur.

e. Isolasi sosial adalah kondisi kesendirian yang dialami oleh individu dan diterima sebagai ketentuan oleh orang lain dan sebagai suatu kecelakaan yang negatif mengancam.

\subsubsection{Fase Halusinasi}

Halusinasi terbagi atas beberapa fase, yaitu sebagai berikut:(Sari, 2019):

a. Fase sleep disorder

Klien merasa banyak masalah, ingin menghindar dari lingkungan, takut diketahui oleh orang lain bahwa dirinya banyak masalah. Masalah semakin terasa sulit karena berbagai stressor terakumulasi, misalnya terlibat narkoba, drop out dari kampus, putus cinta. Masalah terasa semakin menekan dan persepsi terhadap masalah semakin buruk, mengalami sulit tidur berangsur terus-menerus hingga terbiasa menghayal. Klien menganggap lamunan-lamunan awal sebagai pemecahan masalah.

b. Fase comforting

Klien mengalami emosi yang berlanjut seperti adanya perasaan cemas, kesepian, perasaan berdosa, ketakutan dan memusatkan pemikiran pada timbulnya kecemasan, beranggapan bahwa pengalaman pikiran dan sensorinya dapat di kontrol bila 
kecemasannya diatur, dalam tahap ini ada kecenderungan klien merasa nyaman dengan halusinasi.

c. Fase condemnig

Pengalaman sensori klien menjadi sering datang dan mengalami bias atau prasangka. Klien merasa tidak mampu lagi mengontrolnya dan mulai menjaga jarak antara dirinya dengan objek yang dipersepsikan, klien mulai menarik diri dari orang lain dengan intensitas waktu yang lama.

d. Fase controlling

Klien mencoba melawan suara-suara atau sensory abnormal yang datang. Klien dapat merasakan kesepian bila halusinasinya berakhir, disinilah dimulai gangguan pyschotic.

e. Fase conquering

Pengalaman sensorinya terganggu, klien mulai merasa terancam dengan datangnya suara-suara terutama bila klien tidak dapat menuruti ancaman atau perintah yang ia dengar dari halusinasinya. Halusinasi dapat berlangsung 4 jam atau seharian bila klien tidak mendapatkan komunikasi terapeutik. Terjadi gangguan psikotik berat

\subsubsection{Penatalaksanaan Medis}

Halusinasi merupakan salah satu gejala yang paling sering terjadi pada gangguan Skizofrenia. Dimana Skizofrenia merupakan jenis psikosis, adapun tindakan penatalaksanaan dilakukan dengan berbagai terapi (Pardede, Keliat, $\&$ Wardani, 2013) yaitu :

\section{Psikofarmakologis}

Obat sangat penting dalam pengobatan skizofrenia, karena obat dapat membantu klien skizofrenia untuk meminimalkan gejala perilaku kekerasan, halusinasi, dan harga diri rendah. Sehingga klien skizofrenia harus patuh minum obat secara teratur dan mau mengikuti perawatan.

a. Haloperidol (HLD) 
Obat yang dianggap sangat efektif dalam pengelolaan hiperaktivitas, gelisah, agresif, waham, dan halusinasi.

b. Chlorpromazine (CPZ)

Obat yang digunakan untuk gangguan psikosis yang terkait skizofrenia dan gangguan perilaku yang tidak terkontrol

c. Trihexilpenidyl (THP)

Obat yang digunakan untuk mengobati semua jenis parkinson dan pengendalian gejala ekstrapiramidal akibat terapi obat.

1. Dosis

a) Haloperidol $3 \times 5 \mathrm{mg}$ (tiap 8 jam) intra muscular.

b) Clorpromazin $25-50 \mathrm{mg}$ diberikan intra muscular setiap 6-8 jam sampai keadaan akut teratasi.

2. Dalam keadaan agitasi dan hiperaktif diberikan tablet:

a) Haloperidol $2 \times 1,5-2,5 \mathrm{mg}$ per hari.

b) Klorpromazin $2 \times 100 \mathrm{mg}$ per hari

c) Triheksifenidil $2 \times 2 \mathrm{mg}$ per hari

3. Dalam keadaan fase kronis diberikan tablet:

a) Haloperidol $2 \times 0,5-1 \mathrm{mg}$ perhari

b) Klorpromazin 1x50 mg sehari (malam)

c) Triheksifenidil $1-2 \times 2 \mathrm{mg}$ sehari

d) Psikosomatik

2. Terapi kejang listrik (Electro Compulsive Therapy), yaitu suatuterapi fisik atau suatu pengobatan untuk menimbulkan kejang grand mal secara artifisial dengan melewatkan aliran listrik melalui elektroda yang dipasang pada satu atau dua temples pada pelipis. Jumlah tindakan yang dilakukan merupakan rangkaian yang bervariasi pada setiap klien tergantung pada masalah klien dan respon terapeutik sesuai hasil pengkajian selama tindakan. Pada klien Skizofrenia biasanya diberikan 30 kali. ECT biasanya diberikan 3 kali seminggu walaupun biasanya diberikan jarang atau lebih sering. Indikasi penggunaan obat: penyakit depresi berat yang tidak berespon terhadap obat, 
gangguan bipolar di mana klien sudah tidak berespon lagi terhadap obat dan klien dengan bunuh diri akut yang sudah lama tidak mendapatkan pertolongan.

3 Psikoterapi

Membutuhkan waktu yang relatif lama, juga merupakan bagian penting dalam proses terapeutik. Upaya dalam psikoterapi ini meliputi: memberikan rasa aman dan tenang, menciptakan lingkungan terapeutik, memotivasi klien untuk dapat mengungkapkan perasaan secara verbal, bersikap ramah, sopan, dan jujur terhadap klien.

\subsubsection{Komplikasi}

Halusinasi dapat menjadi suatu alasan mengapa klien melakukan tindakan perilaku kekerasan karena suara-suara yang memberinya perintah sehingga rentan melakukan perilaku yang tidak adaptif. Perilaku kekerasan yang timbul pada klien skizofrenia diawali dengan adanya perasaan tidak berharga, takut dan ditolak oleh lingkungan sehingga individu akan menyingkir dari hubungan interpersonal dengan orang lain,komplikasi yang dapat terjadi pada klien dengan masalah utama gangguan sensori persepsi: halusinasi, antara lain: resiko prilaku kekerasan, harga diri rendah dan isolasi sosial(Keliat, 2014).

\subsection{Konsep Asuhan Keperawatan}

\subsubsection{Pengkajian Keperawatan}

Menurut Yusuf, Rizky \& Hanik (2015 ) faktor-faktor terjadinya halusinasi meliputi:

Faktor predisposisi

1. Faktor perkembangan

Hambatan perkembangan akan mengganggu hubungan interpersonal yang dapat meningkatkan stres dan ansietas yang dapat berakhir 
dengan gangguan persepsi. Pasien mungkin menekan perasaannya sehingga pematangan fungsi intelektual dan emosi tidak efektif Faktor sosial budaya

\section{Faktor sosial budaya}

Berbagai faktor di masyarakat yang membuat seseorang merasa disingkirkan atau kesepian, selanjutnya tidak dapat diatasi sehingga timbul akibat berat seperti delusi dan halusinasi

\section{Faktor psikologis}

Hubungan interpersonal yang tidak harmonis, serta peran ganda atau peran yang bertentangan dapat menimbulkan ansietas berat terakhir dengan pengingkaran terhadap kenyataan, sehingga terjadi halusinasi.

\section{Faktor biologis}

Struktur otak yang abnormal ditemukan pada pasien gangguan orientasi realitas, serta dapat ditemukan atropik otak, pembesaran ventikal, perubahan besar, serta bentuk sel kortikal dan limbik.

\section{Faktor genetik}

Gangguan orientasi realitas termasuk halusinasi umumnya ditemukan pada pasien skizofrenia. Skizofrenia ditemukan cukup tinggi pada keluarga yang salah satu anggota keluarganya mengalami skizofrenia, serta akan lebih tinggi jika kedua orang tua skizofrenia.

\section{Faktor Presipitasi}

1. Stresor sosial budaya Stres dan kecemasan akan meningkat bila terjadi penurunan stabilitas keluarga, perpisahan dengan orang yang penting, atau diasingkan dari kelompok dapat menimbulkan halusinasi

2. Faktor biokimia Berbagai penelitian tentang dopamin, norepinetrin, indolamin, serta zat halusigenik diduga berkaitan dengan gangguan orientasi realitas termasuk halusinasi

3. Faktor psikologis Intensitas kecemasan yang ekstrem dan memanjang disertai terbatasnya kemampuan mengatasi masalah memungkinkan berkembangnya gangguan orientasi realitas. Pasien mengembangkan 
koping untuk menghindari kenyataan yang tidak menyenangkan.

4. Perilaku Perilaku yang perlu dikaji pada pasien dengan gangguan orientasi realitas berkaitan dengan perubahan proses pikir, afektif persepsi, motorik, dan sosial

\subsubsection{Diagnosa Keperawatan}

Diagnosa keperawatan merupakan suatu penilaian klinis mengenai respons klien terhadap masalah kesehatan atau proses kehidupan yang dialaminya baik yang berlangsung aktual maupun potensial Diagnosa keperawatan yang dapat ditegakkan antara lain (Cressella, 2020) :
a. Gangguan persepsi sensori: Halusinasi pendengaran
b. Resiko Perilaku kekerasan
c. Harga Diri Rendah

\subsubsection{Perencanaan Keperawatan}

Rencana tindakan pada keluarga (Keliat, 2014) adalah ;

1. Diskusikan masalah yang dihadap keluarga dalam merawat klien

2. Berikan penjelasan meliputi : pengertian halusinasi, proses terjadinya halusinasi, jenis halusinasi yang dialami, tanda dan gejala halusinasi, proses terjadinya halusinasi.

3. Jelaskan dan latih cara merawat anggota keluarga yang mengalami halusinasi : menghardik, minum obat, bercakapcakap, melakukan aktivitas.

4. Diskusikan cara menciptakan lingkungan yang dapat mencegah terjadinya halusinasi.

5. Diskusikan tanda dan gejala kekambuhan

6. Diskusikan pemanfaatan fasilitas pelayanan kesehatan terdekat untuk follow up anggota keluarga dengan halusinasi.

Rencana tindakan keperawatan pada klien dengan diagnosa gangguan persepsi sensori halusinasi meliputi pemberian tindakan keperawatan berupa terapi (Sulah, Pratiwi,\& Teguh. 2016) yaitu : 
1. Bantu klien mengenal halusinasinya meliputio isi, waktu terjadi halusinasi, isi, frekuensi, perasaan saat terjadi halusinasi respon klien terhadap halusinasi mengontrol halusinasi dengan cara menghardik,

2. Meminum obat secara teratur.

3. Melatih bercakap-cakap dengan orang lain,

4. Menyusunkegiatan terjadwal dan dengan aktifitas

\subsubsection{Implementasi}

Implementasi adalah tahapan ketika perawat mengaplikasikan ke dalam bentuk intervensi keperawatan guna membantu klien mencapai tujuan yang telah di tetapkan. Kemampuan yang harus dimiliki oleh perawat pada tahap implementasi adalah kemampuan komunikasi yang efektif, kemampuan utnuk menciptakan saling percaya dan saling membantu, kemampuan melakukan teknik, psikomotor, kemampuan melakukan observasi sistemis, kemampuan memberikan pendidikan kesehatan, kemampuan advokasi dan kemampuan evaluasi (Anggit, 2021 )

\subsubsection{Evaluasi Keperawatan}

Evaluasi adalah proses hasil atau sumatif dilakukan dengan membandingkan respon klien pada tujuan umum dan tujuan khusus yang telah ditentukan.halusinasi pendengaran tidak terjadi perilaku kekerasan, klien dapat membina hubungan saling percaya, klien dapat mengenal halusinasinya, klien dapat mengontrol halusinasi dengar dari jangka waktu 4x24 jam didapatkan data subjektif keluarga menyatakan senang karena sudah diajarkan teknik mengontrol halusinasi, keluarga menyatakan klien mampu melakukan beberapa teknik mengontrol halusinasi. Data objektif klien tampak berbicara sendiri saat halusinasi itu datang, klien dapat berbincang-bincang dengan orang lain, klien mampu melakukan aktivitas terjadwal, dan minum obat secara teratur(Aji, 2019) 


\section{BAB 3 \\ TINJAUAN KASUS}

\subsection{Identitas Klien}

Inisial

Tanggal Pengkajian

Umur

Agama

Informan
: Tn. M

: 4 Maret 2021

: 40 Tahun

: Kristen

: Klien

\subsection{Alasan Masuk}

Klien Awalnya marah-marah dan melempar barang-barang karena kesal, suka menyendiri, melamun, sering bicara sendiri, mondar mandir, mendengar suara-suara tanpa wujud, tertawa sendiri.

Masalah keperawatan : Gangguan Sensori Persepsi Halusinasi Pendengaran

\subsection{Faktor Predisposisi}

Klien sebelumnya pernah mengalami gangguan jiwa \pm 3 tahun yang lalu tepatnya pada tahun 2019 dan pulang kerumah dalam keadaan tenang. Dirumah klien tidak rutin minum obat, tidak mau kontrol ke RSJ sehingga timbul gejala-gejala seperti diatas kemudian klien kambuh lagi. Klien awalnya marah-marah dan melempar barang-barang karena kesal, suka menyendiri, melamun, sering bicara sendiri, mondar mandir, mendengar suara-suara tanpa wujud, tertawa sendiri akhirnya keluarga membawa klien kembali ke rumah dan di rawat keluarga

Masalah keperawatan : Gangngguan Sensori Persepsi Halusinasi Pendengaran.

\subsection{Fisik}

Klien tidak memiliki keluhan fisik, saat dilakukan pemeriksaan tanda-tanda vital, didapatkan hasil TD : 110/80 mmHg ; $\mathrm{N}: 82 \mathrm{x} / \mathrm{i}$; S : 36,5 ${ }^{\circ} \mathrm{C}$; P : 20x/i. Klien memiliki tinggi badan $170 \mathrm{~cm}$ dan berat badan $65 \mathrm{Kg}$. 


\subsection{Psikososial}

\subsubsection{Genogram}

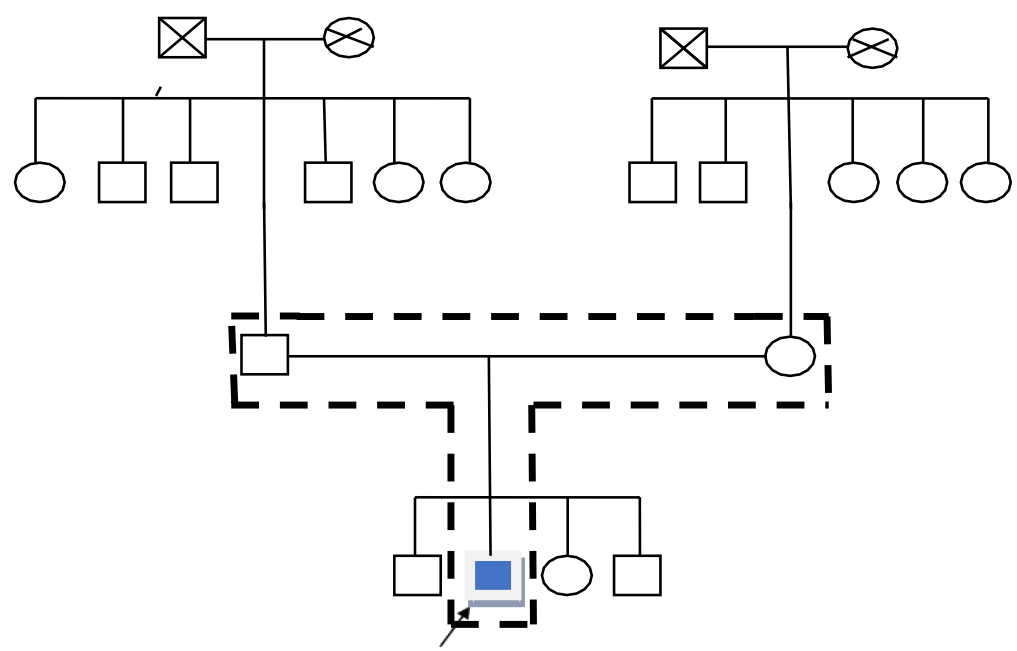

Jelaskan :

klien merupakan anak ke 2 dari 4 bersaudara, klien tinggal serumah dengan ayah dan ibu kandungnya, klien selalu terbuka dengan apa yang dialaminya saat ini kepada semua keluarganya, namun orang yang pertama kali didatangi untuk diceritakan ialah ibu kandung klien

Keterangan :

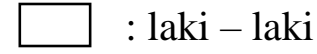

: Perempuan

: Klien

— : Tinggal serumah

\subsubsection{Konsep diri}

a. Gambaran diri: Klien menyukai seluruh tubuhnya dan tidak ada yang cacat

b. Identitas : $\quad$ Klien anak ke 2 dari 4 bersaudara.

c.Ideal diri $\quad: \quad$ Klien merasa malu ke tetangga karena klien beranggapan di jauhin oleh keluarga. 
a. Harga diri : Klien mengatakan merasa malu terhadap keluarga dan lingkungan atau tetangga Masalah keperawatan: Gangguan Konsep Diri : Harga Diri Rendah

\subsubsection{Hubungan social}

Klien mengganggap bahwa keluarganya adalah orang yang sangat berarti dalam hidupnya, terutama orangtuanya. Klien mengatakan tidak mengikuti kegiatan di kelompok/masyarakat. Klien mengatakan mempunyai hambatan dalam berhubungan dengan orang lain karena klien sulit bergaul dan selalu ingin menyendiri. Masalah keperawatan: Isolasi Sosial : Menarik Diri

\subsubsection{Spiritual}

a. Nilai dan Keyakinan: Klien beragama kristen dan yakin dengan agamanya.

b. Kegiatan Ibadah :Klien melakukan ibadah sekali semingggu

\subsubsection{Status Mental}

1. Penampilan klien rapi seperti berpakaian biasa pada umum nya

2. Pembicaraan

Klien bicara dengan lambat.

3. Aktivitas Motorik

Klien mengatakan bisa melakukan aktivitas sehari - hari.

4. Alam perasaan

Klien sedih karena tinggal di yayasan, terlebih keluarga jarang datang menjenguk. klien sangat rindu dengan keluarga nya.

Masalah keperawatan ; Harga Diri Rendah

5. Afek

Afek wajah datar, klien menjawab pertanyaan dari perawat.

6. Interaksi selama wawancara

Klien kooperatif saat wawancara

7. Persepsi 
Klien mengatakan bahwa ia mendengar ada suara-suara

Masalah keperawatan : Gangguan persepsi sensori : halusinasi

8. Proses Pikir

Klien mampu menjawab apa yang ditanya dengan

9. Isi pikir

Klien dapat mengontrol isi pikirnya,klien tidak mengalami gangguan isi pikir dan tidak ada waham. Klien tidak mengalami fobia, obsesi ataupun depersonalisasi.

10. Tingkat kesadaran

Klien tidak mengalami gangguan orientasi, klien mengenali waktu, orang dan tempat.

11. Memori

Klien mampu menceritakan kejadian di masa lalu dan yang baru terjadi.

12. Tingkat konsentrasi berhitung

Klien mampu berkonsentrasi dalam perhitungan sederhana tanpa bantuan orang lain.

13. Kemampuan penilaian

Penjelasan : Klien dapat membedakan hal yang baik dan yang buruk (mampu melakukan penilaian

14. Daya tilik diri

Klien tidak mengingkari penyakit yang diderita, klien mengetahui bahwa dia sedang sakit dan rawat di rumah .

\subsection{Mekanisme Koping}

Klien mengalami mekanisme koping adaptif yaitu klien dapat berbicara baik dengan orang lain

\subsection{Masalah Psikososial dan Lingkungan}

Klien mengatakan sulit berteman dengan orang lain karena klien selalu ingin melempar batu ke tetangga. 
Masalah keperawatan :

\subsection{Pengetahuan Kurang Tentang Gangguan Jiwa}

Klien tidak mengetahui tentang gangguan jiwa yang di alaminya dan obat yang dikonsumsinya.

\subsection{Aspek Medik}

Diagnosa medis : Skizofrenia Paranoid

Terapi medis yang diberikan:

a. Resperidon tablet $2 \mathrm{mg} 2 \times 1$

b. Chlozapine tablet $25 \mathrm{mg} 1 \times 1$

\subsection{Analisa Data}

\begin{tabular}{|c|c|c|}
\hline No & Data & Masalah keperawatan \\
\hline 1 & $\begin{array}{l}\text { Ds : } \\
\text { - Keluarga klien mengatakan } \\
\text { bahwa klien sering berteriak } \\
\text { - Klien sering mendengarkan } \\
\text { suara - suara tampa wajah } \\
\text { yang menyuruhnya } \\
\text { - Klien mengatakan suara - suara } \\
\text { tersebut muncul } 3 \text { kali / hari, } \\
\text { muncul pada saat klien sedang } \\
\text { menyendiri } \\
\text { - Klien merasa gelisah dan takut } \\
\text { jika mendengar suara tersebut } \\
\text { Do : } \\
\text { - Klien sering marah - marah, } \\
\text { mondar - mandir, bicara } \\
\text { sendiri, bicara ngawur, sering }\end{array}$ & $\begin{array}{l}\text { Gangguan persepsi } \\
\text { sensori : halusinasi } \\
\text { pendengaran }\end{array}$ \\
\hline
\end{tabular}




\begin{tabular}{|c|c|c|}
\hline & senyum - senyum sendiri & \\
\hline 2 & $\begin{array}{l}\text { Ds : } \\
\text { Klien mengatakan pernah } \\
\text { melempar barang-barang yang ada } \\
\text { dirumahnya, pernah hampir } \\
\text { memukul keluarganya dan marah- } \\
\text { marah. } \\
\text { Do : } \\
\text { Klien tampak memandang orang lain } \\
\text { dengan tatapan bermusuhan dan } \\
\text { tampak gelisah. }\end{array}$ & Risiko perilaku kekerasan \\
\hline 3. & $\begin{array}{l}\text { Ds : Klien mengatakan ditinggal } \\
\text { oleh istrinya dan merasa minder } \\
\text { dengan orang lain } \\
\text { Do: } \\
\text { Klien tampak malu dan gelisah, dan } \\
\text { tampak sedih saat di kaji }\end{array}$ & $\begin{array}{l}\text { Gangguan harga diri } \\
\text { rendah }\end{array}$ \\
\hline
\end{tabular}

\subsection{Masalah Keperawatan}

1. Gangguan Persepsi Sensori : Halusinasi Pendengaran

2. Resiko perilaku kekerasan

3. Gangguan Konsep Diri : Harga Diri Rendah 


\subsection{Pohon Masalah}

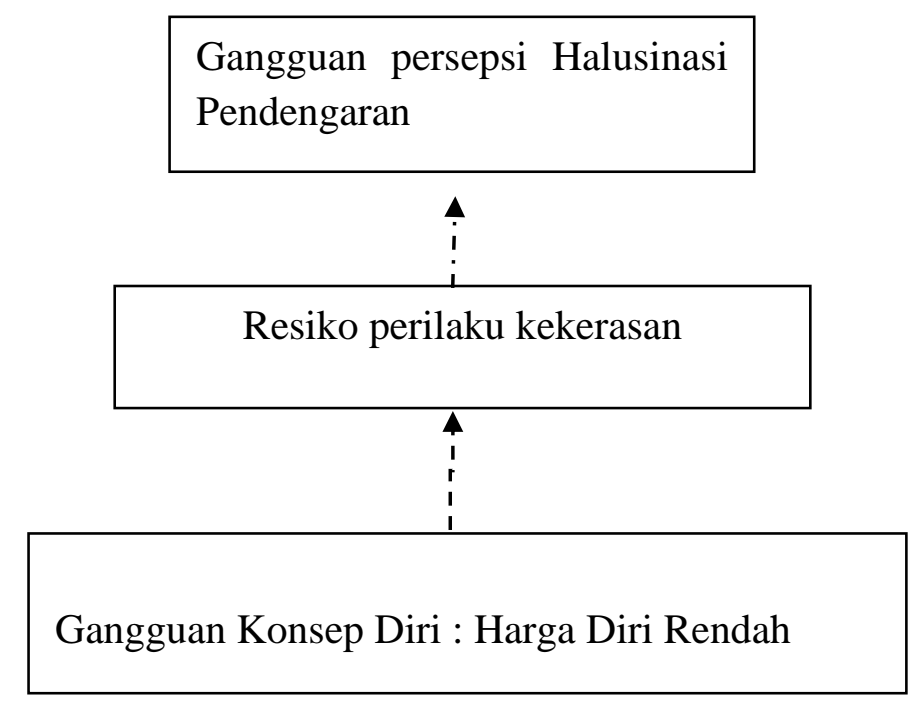

\subsection{Prioritas Diagnosa Keperawatan}

1.Gangguan persepsi Sensorik : Halusinasi pendengaran

2. Resiko perilaku kekerasan

3. Harga diri rendah

\subsection{Intervensi Keperawatan}

\begin{tabular}{|c|c|c|c|c|}
\hline No. & $\begin{array}{l}\text { Diagnosa } \\
\text { Keperawatan }\end{array}$ & Tujuan & Kriteria Hasil & Intervensi \\
\hline 1. & $\begin{array}{l}\text { Gangguan } \\
\text { persepsi } \\
\text { sensori } \\
\text { halusinasi }\end{array}$ & $\begin{array}{l}\text { TUM: } \\
\text { Klien } \\
\text { tidak } \\
\text { mengalam } \\
\text { i } \\
\text { gangguan }\end{array}$ & $\begin{array}{l}\text { 1. Ekspresi wajah } \\
\text { bersahabat, } \\
\text { menunjukkan rasa } \\
\text { senang, ada } \\
\text { kontak mata, mau } \\
\text { berjabat tangan, } \\
\text { mau menyebutkan }\end{array}$ & $\begin{array}{l}\text { 1. Bina hubungan saling } \\
\text { percaya dengan } \\
\text { mengungkapkan prinsip } \\
\text { komunikasi terapeutik: } \\
\text { A.Sapa klien } \\
\text { dengan ramah, }\end{array}$ \\
\hline
\end{tabular}




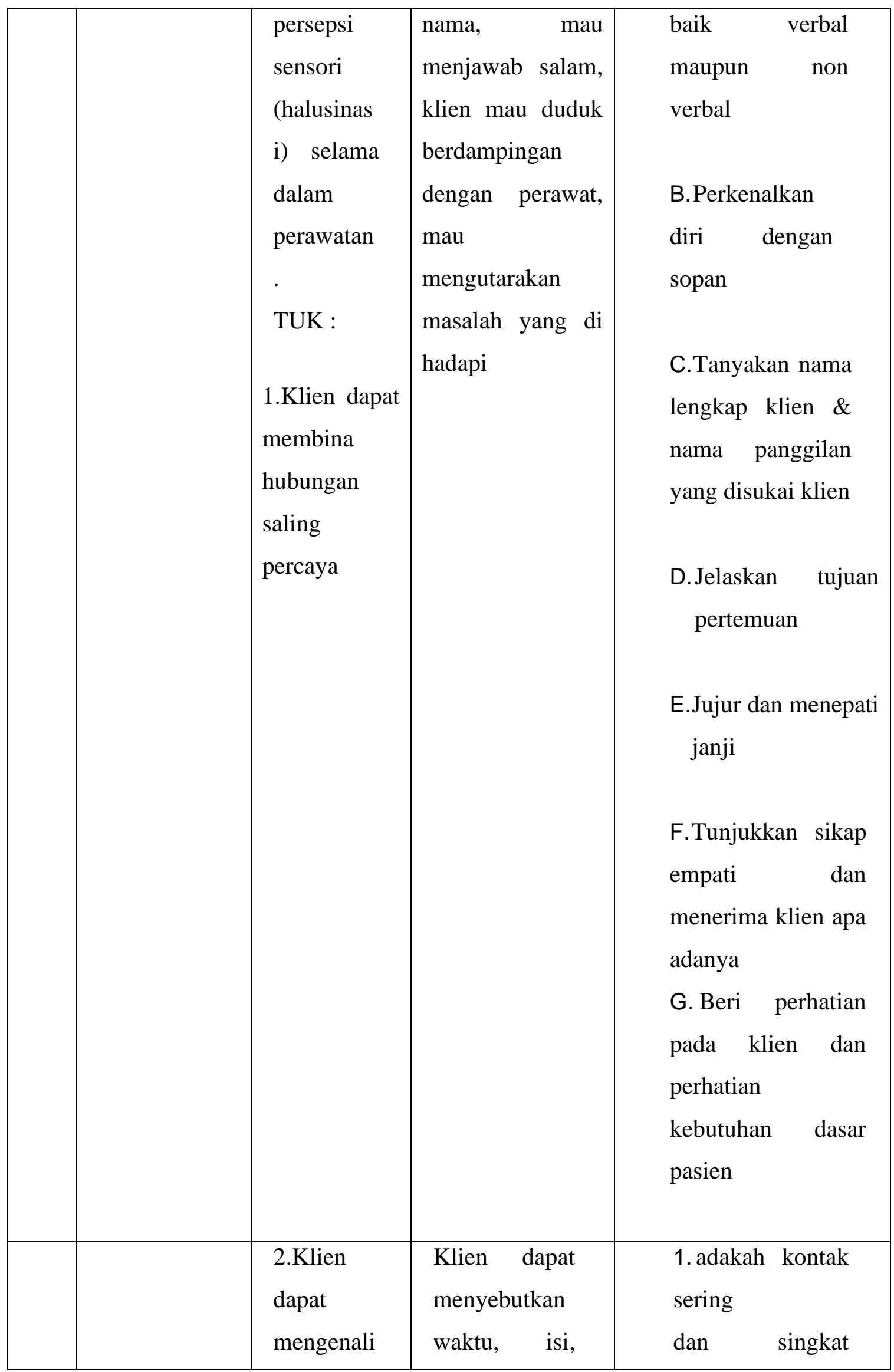




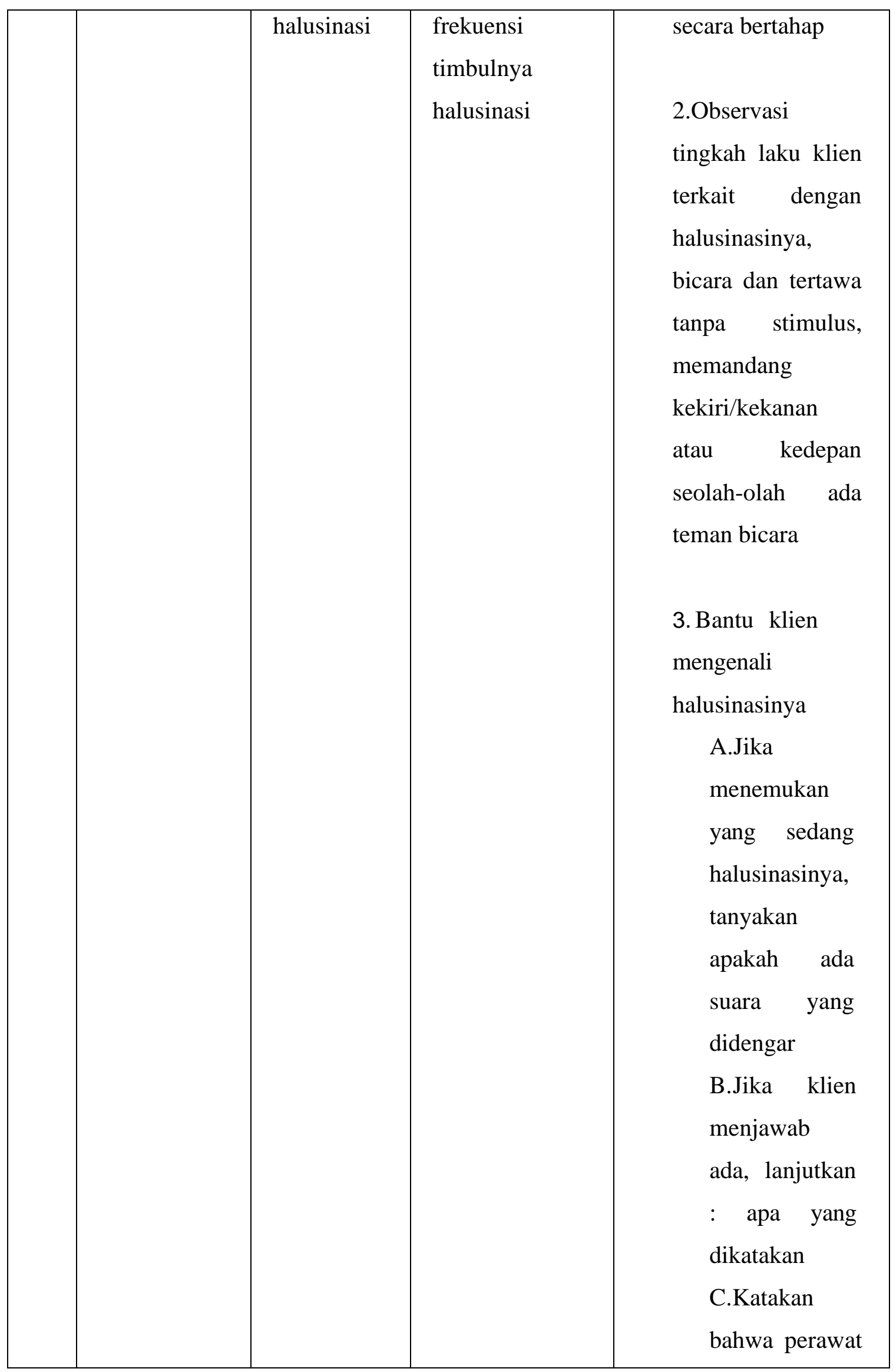




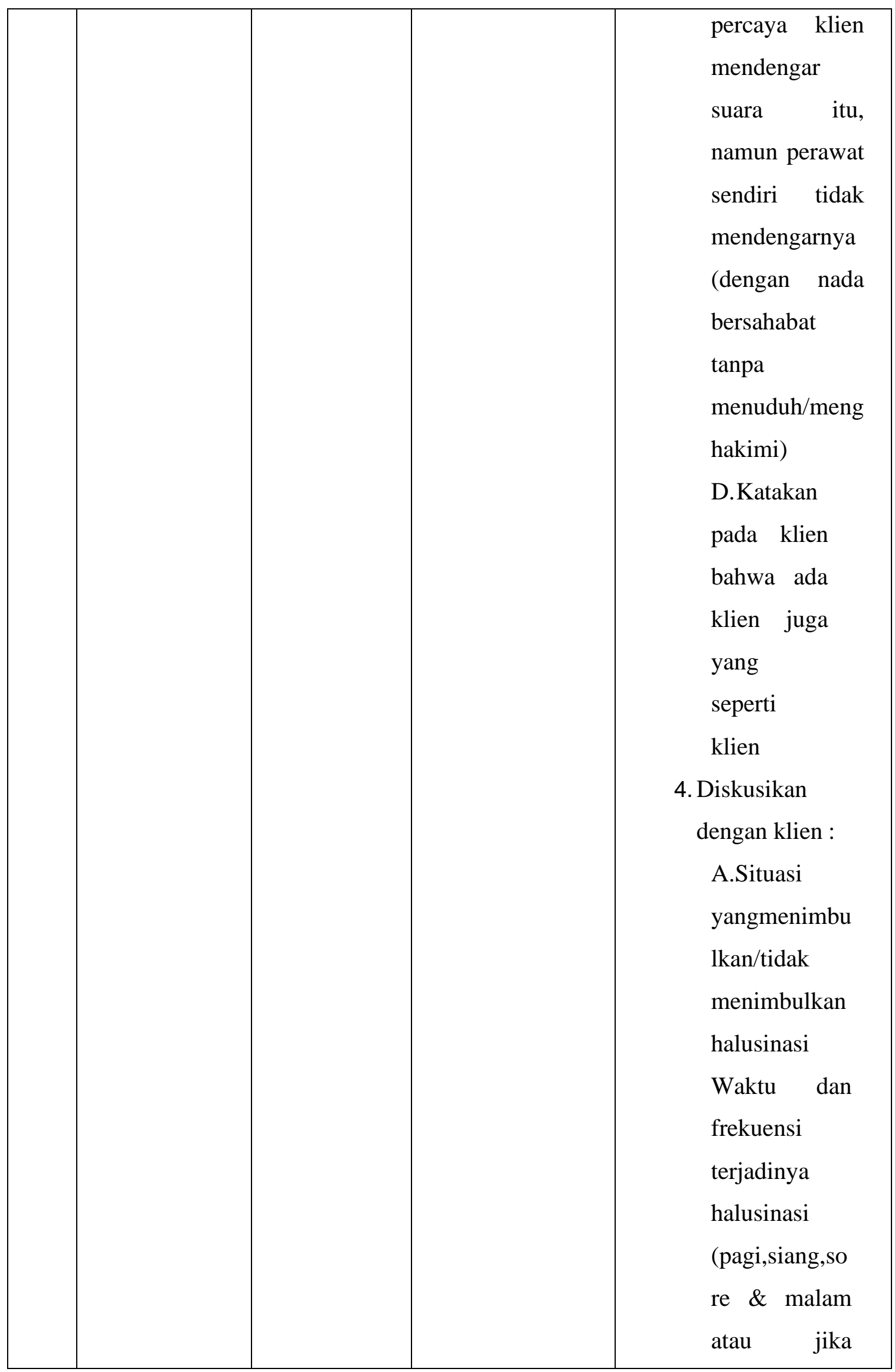




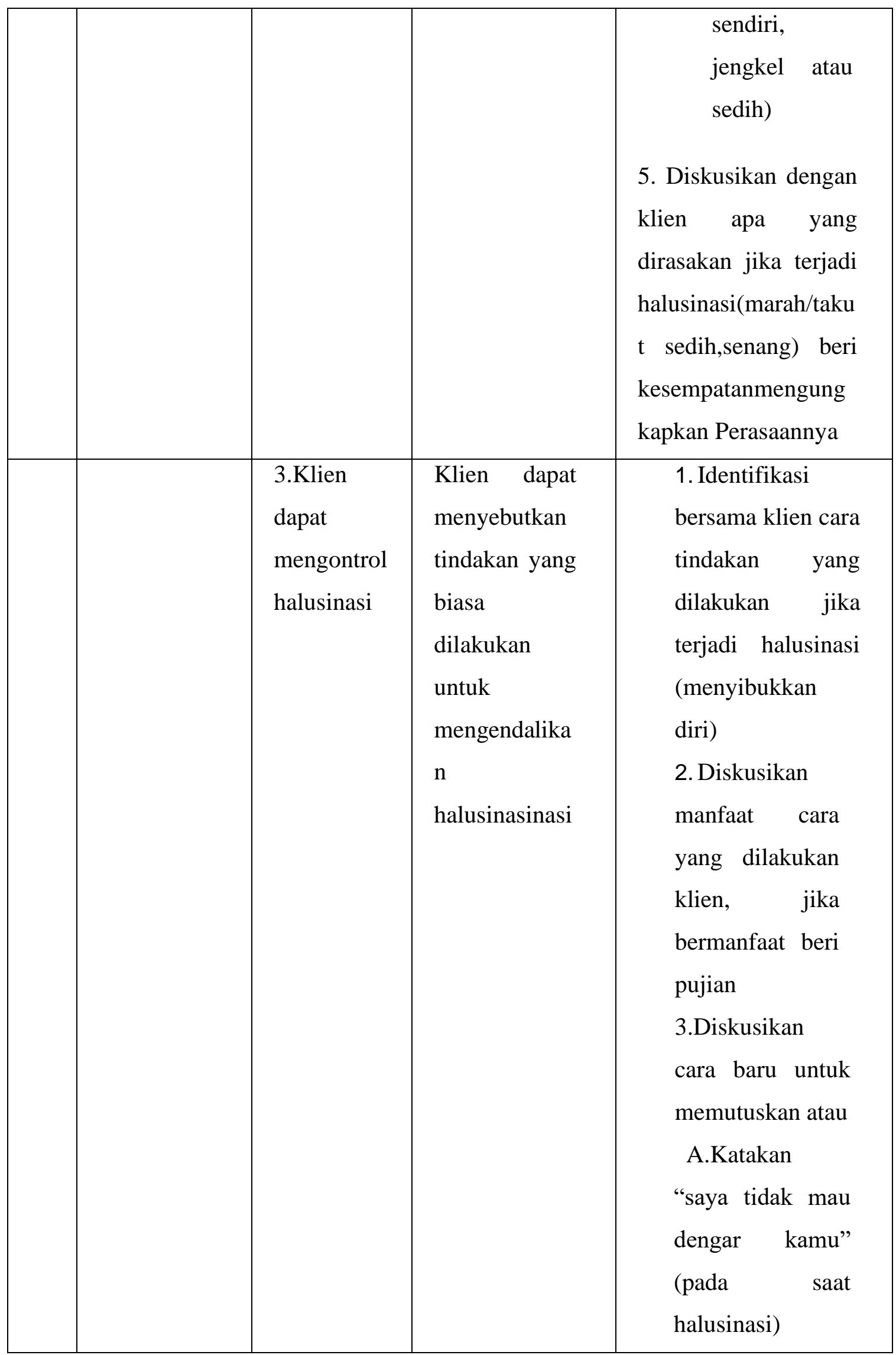




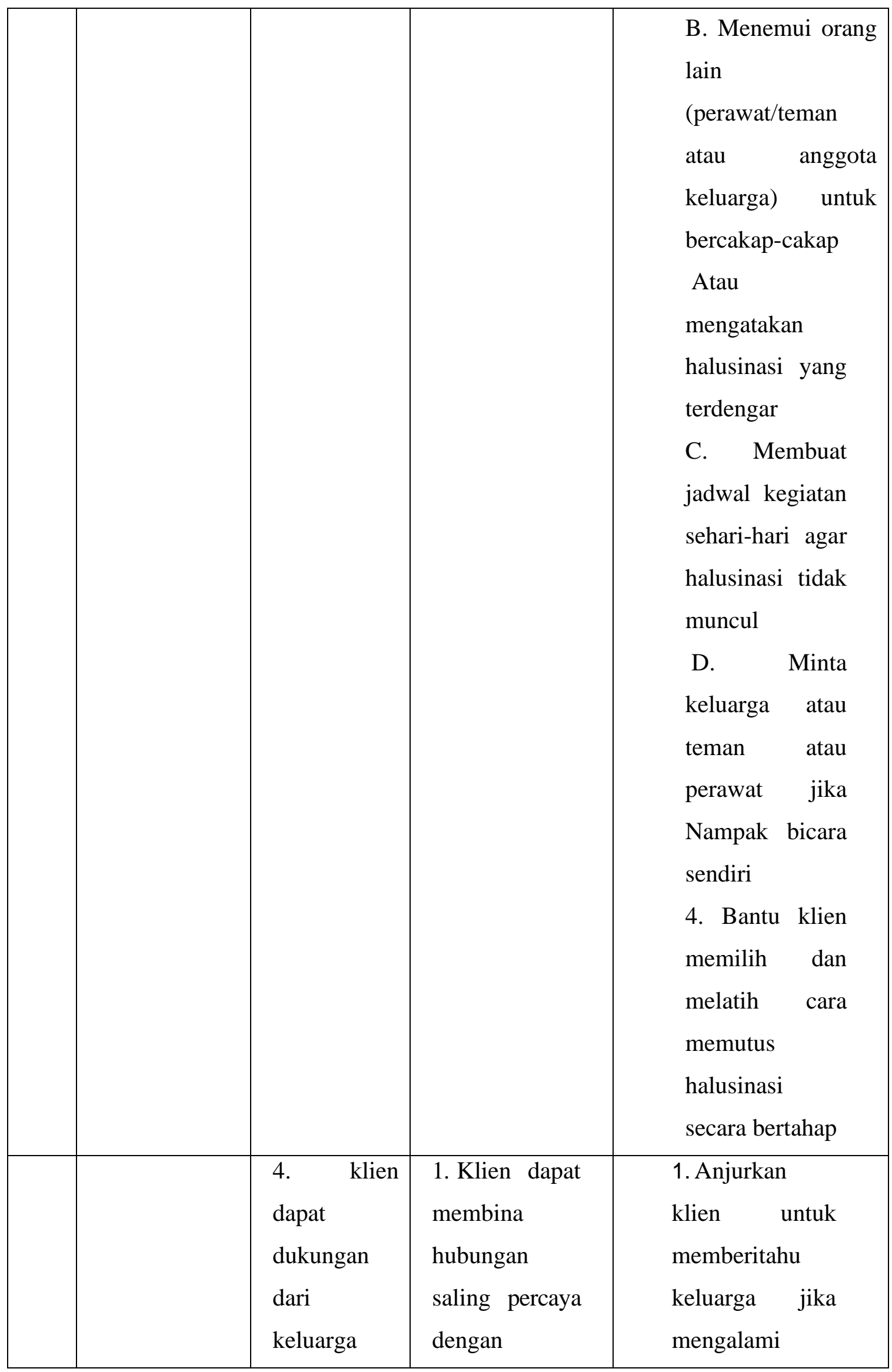




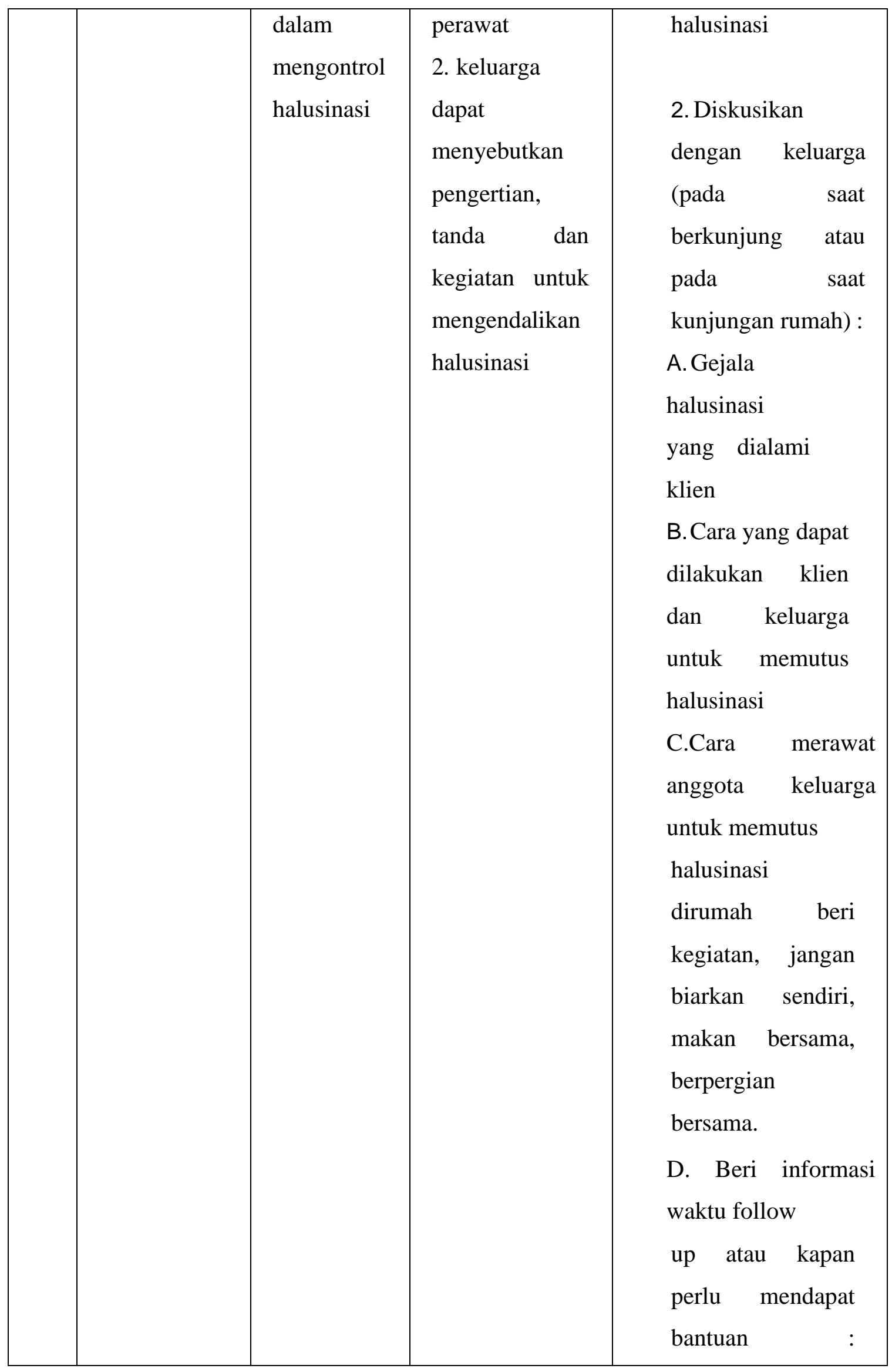




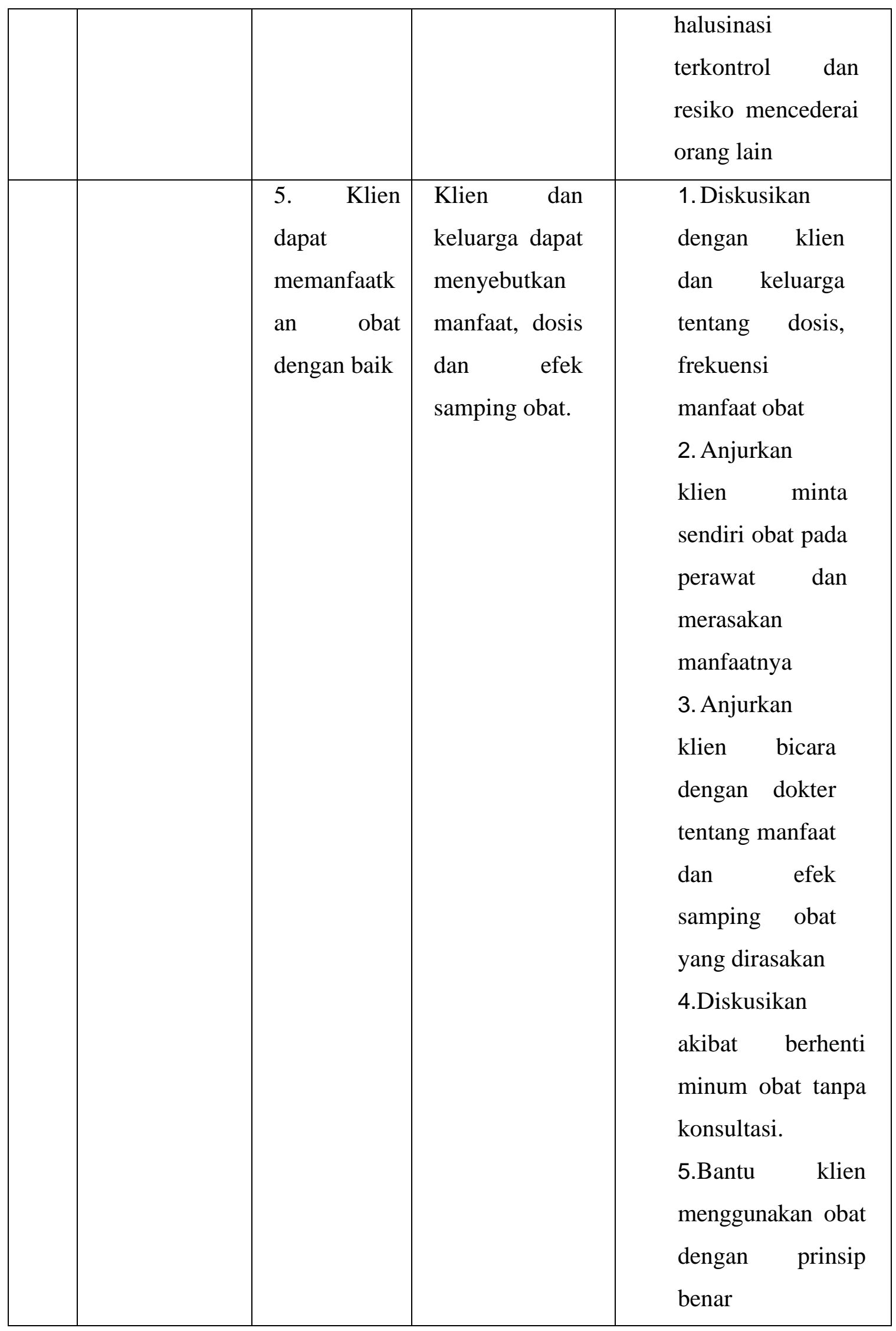




\begin{tabular}{|c|c|c|c|c|}
\hline 2. & $\begin{array}{l}\text { Resiko } \\
\text { Perilaku } \\
\text { kekerasan }\end{array}$ & $\begin{array}{l}\text { klien dapat } \\
\text { mebina } \\
\text { hubungan } \\
\text { saling } \\
\text { percaya }\end{array}$ & $\begin{array}{l}\text { Ketika } \\
\text { di evaluasi } \\
\text { Klien mau } \\
\text { membalas } \\
\text { salam, } \\
\text { Berjabat } \\
\text { tangan,menyeb } \\
\text { utkan nama, } \\
\text { tersenyum, ada } \\
\text { kontak mata, } \\
\text { serta } \\
\text { menyediakan } \\
\text { waktu untuk } \\
\text { kunjungan } \\
\text { berikutnya }\end{array}$ & $\begin{array}{l}\text { 1.Membina } \\
\text { hubungan } \\
\text { saling percaya } \\
\text { dengan cara } \\
\text { (menjelaskan } \\
\text { maksud dan } \\
\text { tujuan interaksi, } \\
\text { jelaskan tentang } \\
\text { kontrak yang } \\
\text { akan dibuat, beri } \\
\text { rasa aman dan } \\
\text { sikap empati) } \\
\text { 2. Diskusikan } \\
\text { bersama klien } \\
\text { tentang perilaku } \\
\text { kekerasan } \\
\text { (penyebab, tanda } \\
\text { dan gejala, } \\
\text { perilaku yang } \\
\text { muncul dan } \\
\text { akibat dari } \\
\text { perilaku } \\
\text { tersebut). }\end{array}$ \\
\hline & & $\begin{array}{l}\text { Klien dapat } \\
\text { mengendali } \\
\text { kan perilaku } \\
\text { kekerasan } \\
\text { dengan cara } \\
\text { relaksasi } \\
\text { nafas dalam } \\
\text { dan pukul } \\
\text { bantal kasur }\end{array}$ & $\begin{array}{l}\text { Klien mampu } \\
\text { menyebutkan } \\
\text { dan } \\
\text { menredemonst } \\
\text { rasi kan cara } \\
\text { mengontrol } \\
\text { perilaku } \\
\text { kekerasan } \\
\text { dengan cara }\end{array}$ & $\begin{array}{l}\text { Sp 1: } \\
\text { Latih klien } \\
\text { melakukan cara } \\
\text { mengontrol } \\
\text { Kemarahan:Ajak } \\
\text { an tehnik } \\
\text { relaksasi nafas } \\
\text { dalamPukul } \\
\text { bantal }\end{array}$ \\
\hline
\end{tabular}




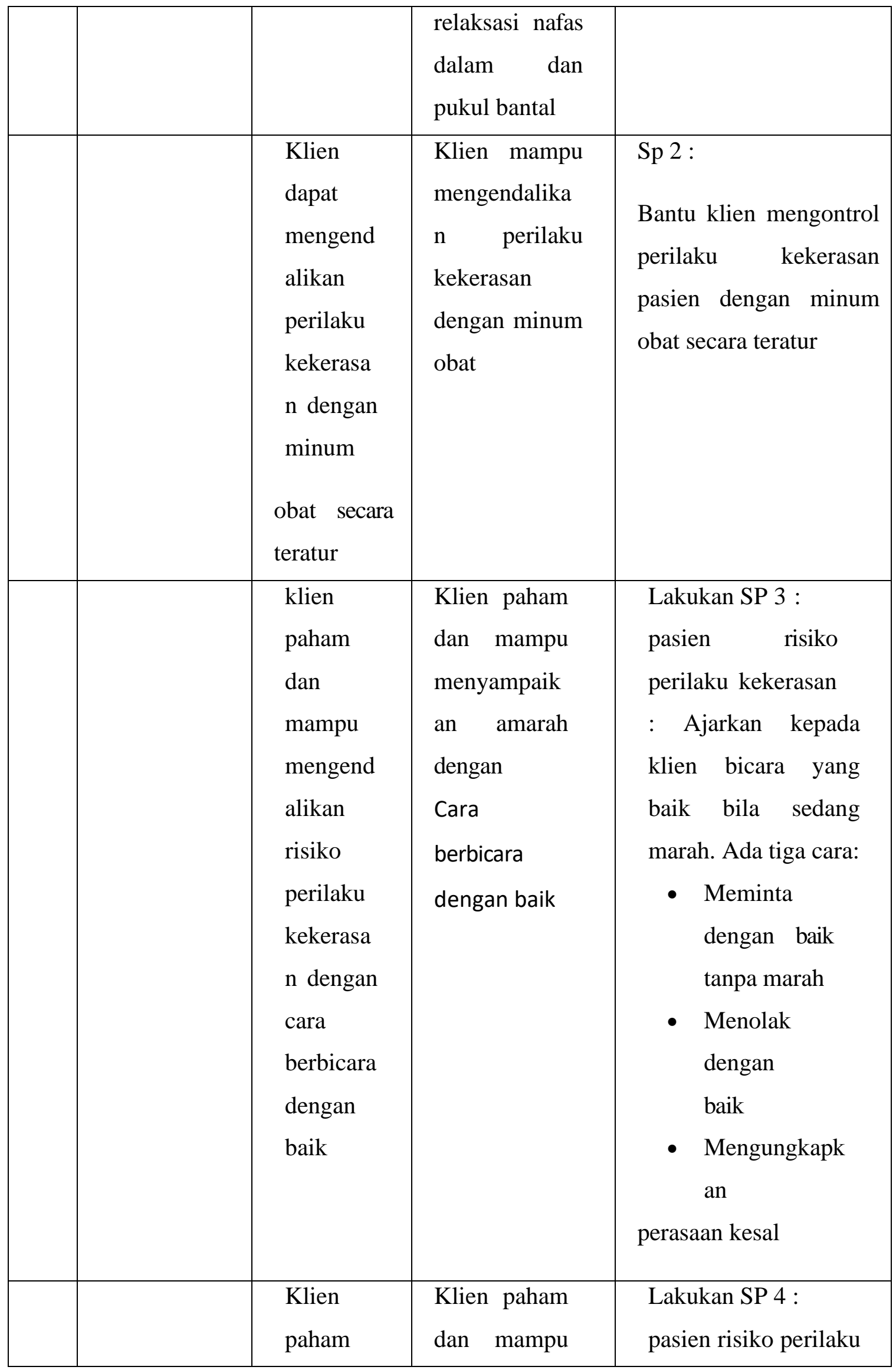




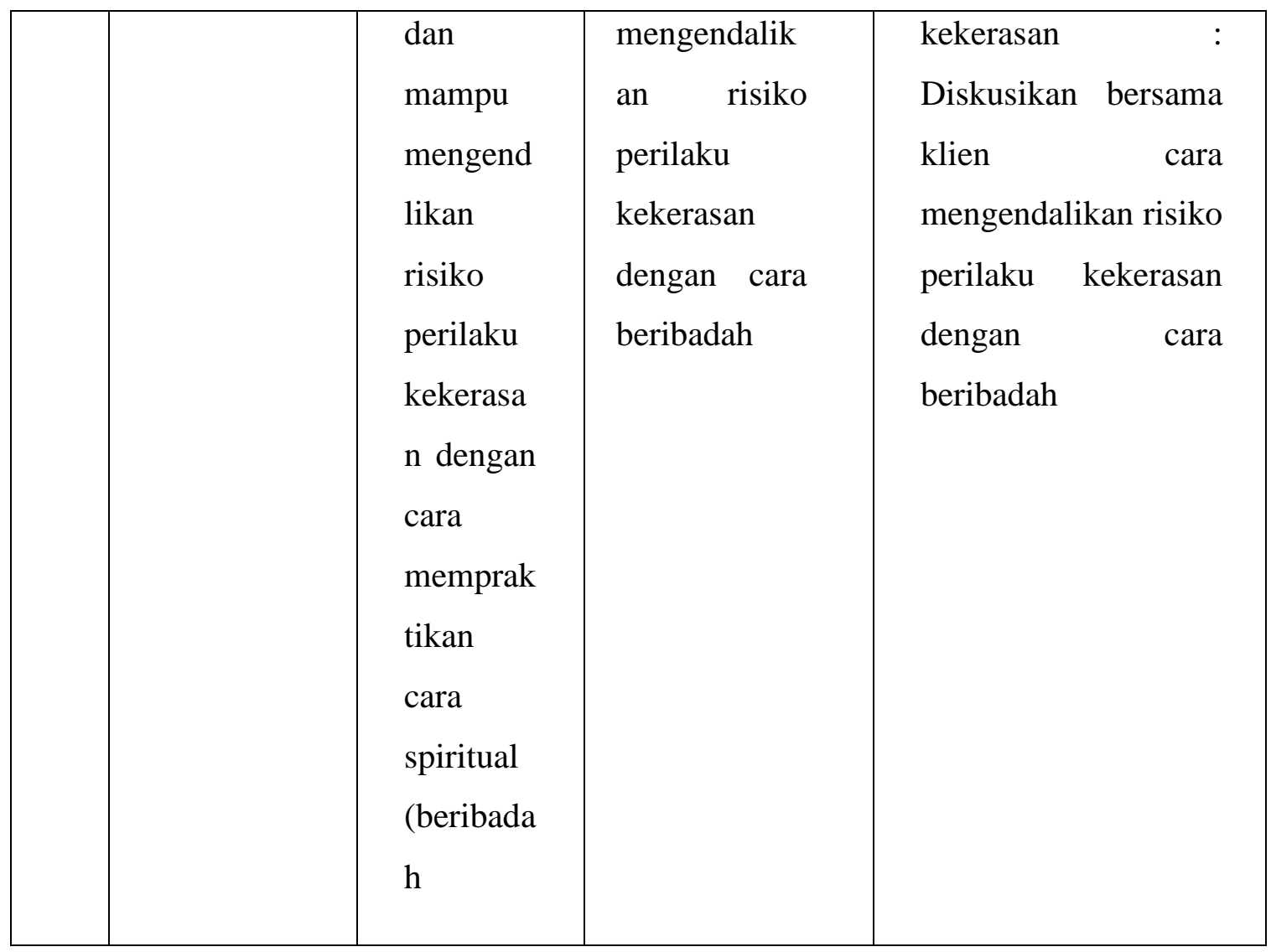

1.15 Implementasi dan Evaluasi

\begin{tabular}{|l|c|l|}
\hline Hari/ tanggal & Implementasi & Evaluasi \\
\hline Kamis & DATA: & S: klien mengatakan \\
$\mathbf{1 6 . 0 0}$ & SP 1 : Klien dapat membina & senang dengan \\
& hubungan saling percaya & $\begin{array}{l}\text { kunjungan } \\
\text { mahasiswa/i }\end{array}$ \\
& $\begin{array}{c}\text { DS : Klien mengatakan mendengar } \\
\text { bisikan- bisikan yang } \\
\text { menyuruhnya untuk } \\
\text { melakukan sesuatu } \\
\text { DO : Kontak mata kurang pada } \\
\text { saat bercerita, pasien juga } \\
\text { tampak mengarahkan } \\
\text { telinga kearah-arah } \\
\text { tertentu } \\
\text { DiagnosaKeperawatan: }\end{array}$ & \\
& \multicolumn{2}{|}{} \\
\hline
\end{tabular}




\begin{tabular}{|c|c|c|}
\hline & $\begin{array}{ll}\text { Gangguan } & \text { persepsi } \\
\text { sensori }: & \text { halusinasi } \\
\text { pendengaran } & \end{array}$ & $\begin{array}{l}\text { O: ada kontak mata, } \\
\text { mau berjabat } \\
\text { tangan, mau } \\
\text { menyebutkan } \\
\text { nama, mau } \\
\text { menjawab salam, } \\
\text { klien mau duduk } \\
\text { berdampingan } \\
\text { dengan perawat, } \\
\text { mau } \\
\text { mengutarakan } \\
\text { masalah yang di } \\
\text { hadapi. } \\
\text { A: SP } 1 \text { teratasi }\end{array}$ \\
\hline $\begin{array}{l}\text { Jumat } \\
05 / 03 / 2021 \\
13.00\end{array}$ & $\begin{array}{l}\text { DATA: } \\
\text { SP } 2 \text { :Klien dapat mengenali } \\
\text { halusinasinya DS : klien } \\
\text { mengatakan senang dengan } \\
\text { kunjungan mahasiswa/i } \\
\text { kesehatan } \\
\text { DO : } \text { ada kontak mata, mau } \\
\text { berjabat tangan, mau } \\
\text { menyebutkan nama, mau } \\
\text { menjawab salam, klien mau } \\
\text { duduk berdampingan dengan } \\
\text { perawat, mau mengutarakan } \\
\text { masalah yang di hadapi. }\end{array}$ & $\begin{array}{l}\text { S: klien mengatakan } \\
\text { sudah menetahui apa } \\
\text { yang dialaminya saat } \\
\text { ini } \\
\text { O: Klien dapat } \\
\text { menyebutkan } \\
\text { waktu, isi, } \\
\text { frekuensi } \\
\text { timbulnya } \\
\text { halusinasi } \\
\text { A: SP } 2 \text { teratasi }\end{array}$ \\
\hline
\end{tabular}




\begin{tabular}{|c|c|c|}
\hline & & P: lanjutkan SP 3 \\
\hline $\begin{array}{l}\text { Sabtu } \\
06 / 03 / 2021 \\
14.00\end{array}$ & $\begin{array}{l}\text { DATA: } \\
\text { SP 3: Klien dapat mengontrol } \\
\text { halusinasinya DS : klien } \\
\text { mengatakan sudah menetahui } \\
\text { apa } \\
\quad \text { yang dialaminya saat ini } \\
\text { DO : Klien dapat } \\
\text { menyebutkan waktu, isi, } \\
\text { frekuensi timbulnya } \\
\text { halusinasi } \\
\text { DiagnosaKeperawatan: } \\
\text { Gangguan persepsi sensori : } \\
\text { halusinasi pendengaran }\end{array}$ & $\begin{array}{l}\text { S: klien } \\
\text { mengatakan } \\
\text { masih mendengar } \\
\text { bisikan-bisikan } \\
\text { pada saat ingin } \\
\text { istirahat dimalam } \\
\text { hari } \\
\text { O: Klien dapat } \\
\text { menyebutkan } \\
\text { tindakan yang } \\
\text { biasa dilakukan } \\
\text { untuk } \\
\text { mengendalikan } \\
\text { halusinasinya } \\
\text { yaitu dengan } \\
\text { cara mencari } \\
\text { kesibukan } \\
\text { P: lanjutkan SP } 3 \text { dan } \\
\text { SP } 4\end{array}$ \\
\hline & $\begin{array}{l}\text { 1. Data: } \\
\text { Tanda dan gejala : mudah } \\
\text { marah- marah, mudah } \\
\text { tersinggung,tatapan }\end{array}$ & $\begin{array}{l}\mathbf{S}: \text { antusias dan } \\
\text { bersemangat } \\
\mathbf{O}:\end{array}$ \\
\hline
\end{tabular}




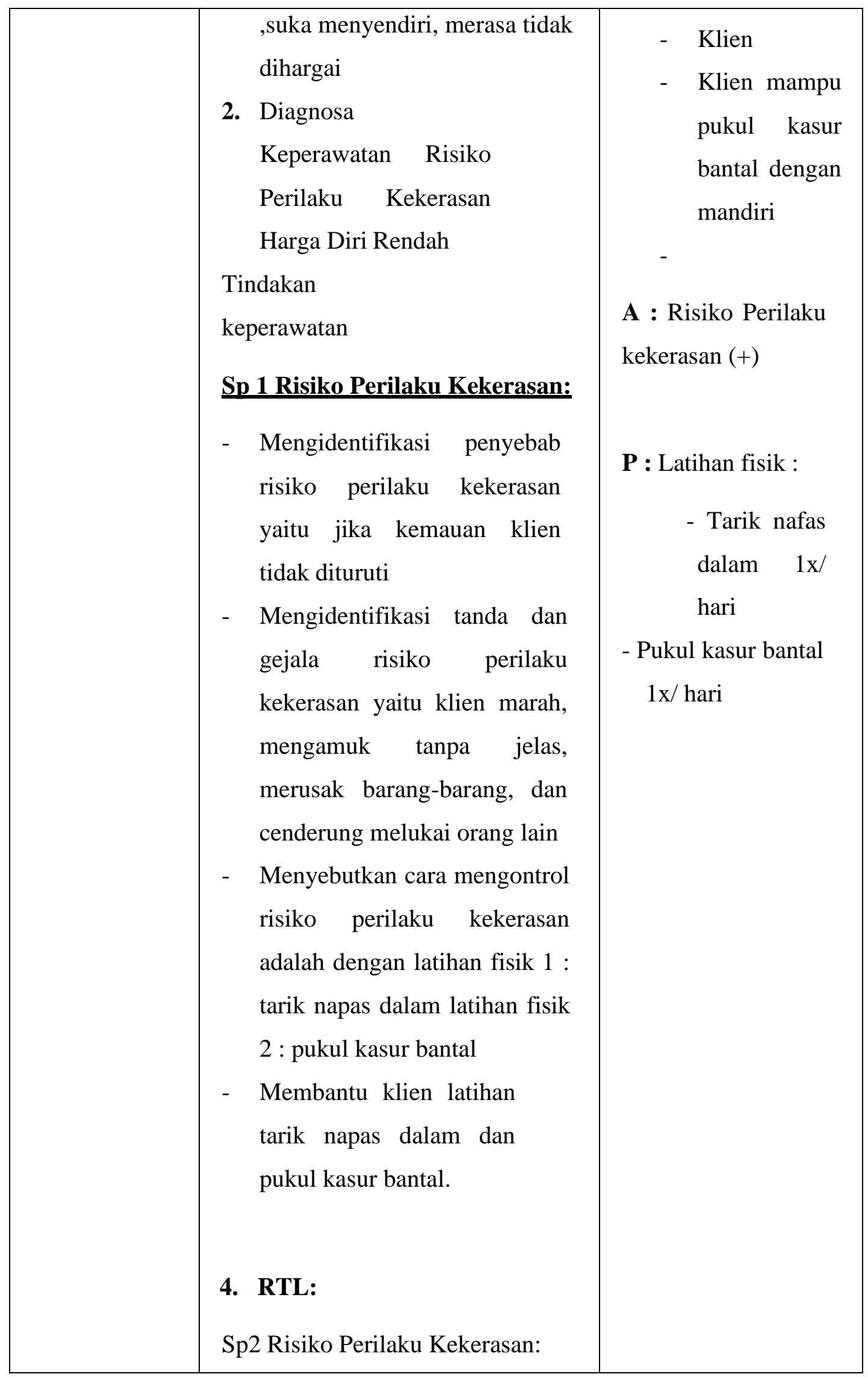




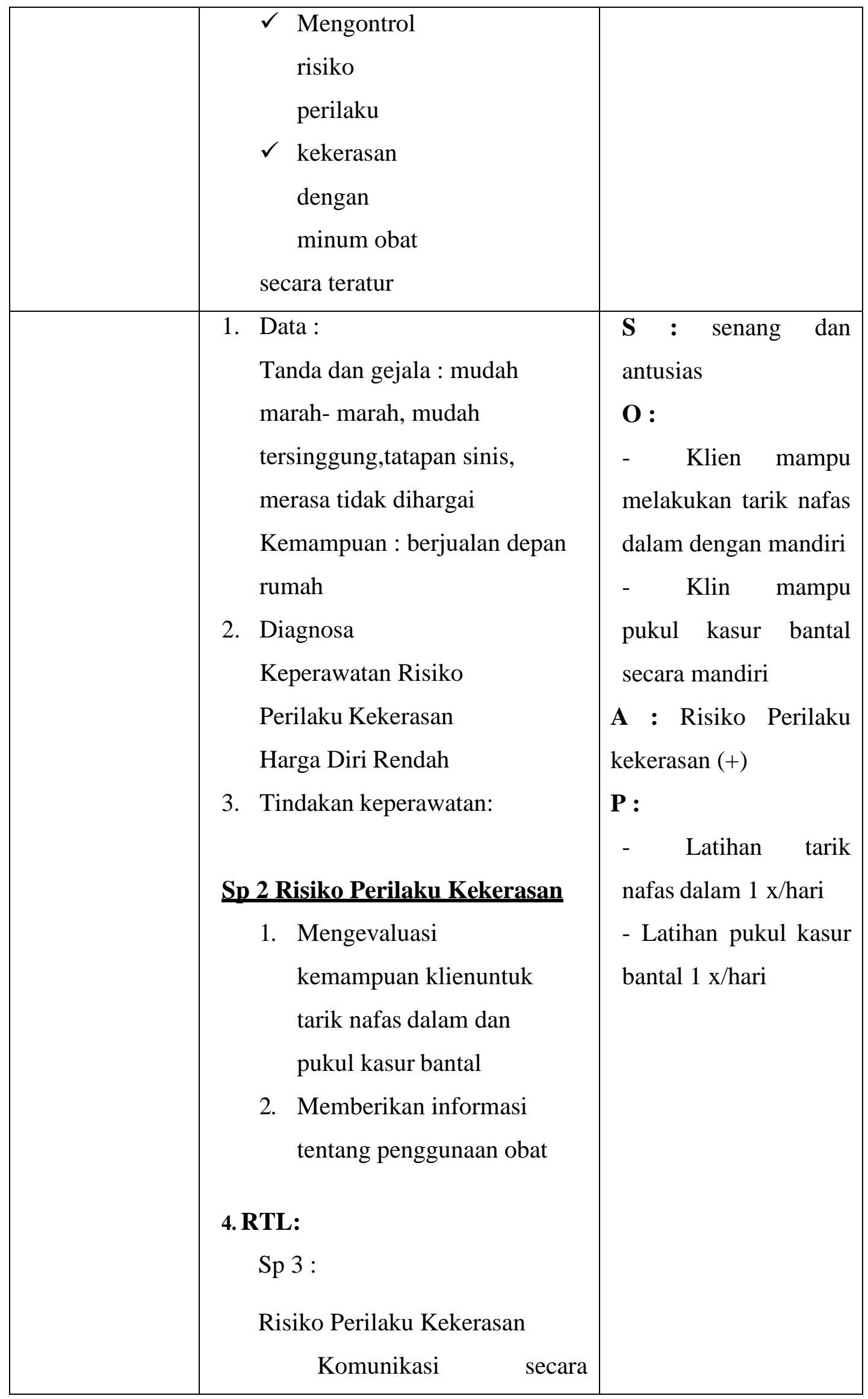




\begin{tabular}{|c|c|c|}
\hline & verbal:Asertif/bicara baik-baik. & \\
\hline $\begin{array}{l}\text { Sabtu } \\
10 / 03 / 2021\end{array}$ & 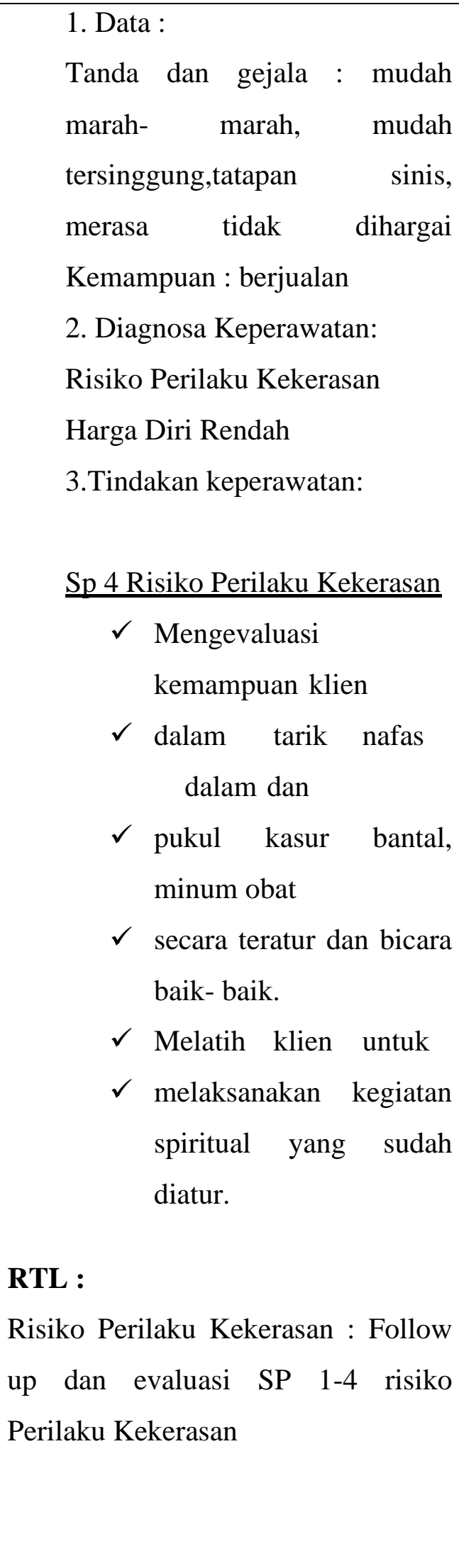 & 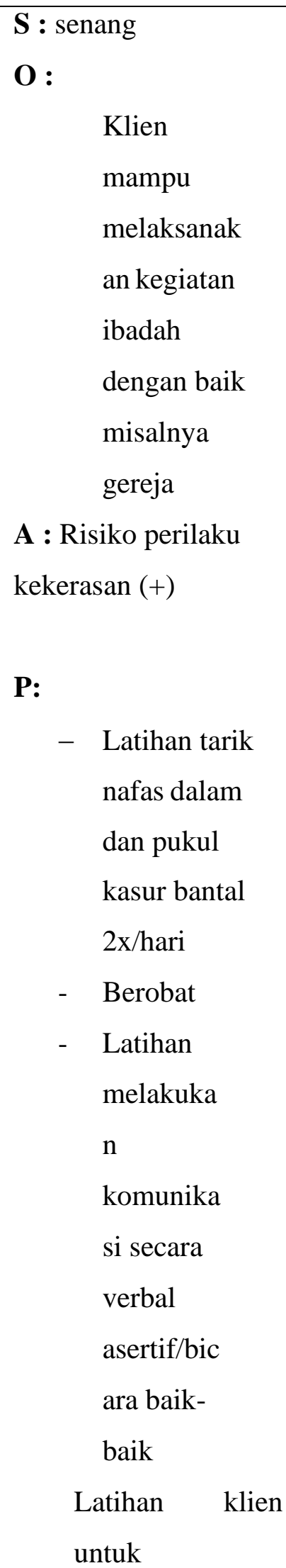 \\
\hline
\end{tabular}




\begin{tabular}{|l|l|}
\hline & melaksanakan \\
& kegiatan spiritual \\
& yang sudah \\
& diatur. \\
\hline
\end{tabular}




\section{BAB 4 \\ PEMBAHASAN}

Setelah penulis melaksanakan asuhan keperawat kepada Tn.M dengan gangguan sensori persepsi: halusinasi pendengaran di Masyarakat sumatra,maka penulis pada BAB ini akan membahasan kesenjangan antara teoritis dengan tinjauan kasus. Pembahasan dimulai melalui tahapan proses keperawatan yaitu pengkajian, diagnosa keparawatan, perencanaan, pelaksanaan dan evaluasi.

\subsection{Pengkajian}

Pada pembahasan ini diuraikan tentang hasil pelaksanaan tindakan keperawatan dengan pemberian terapi generalis pada klien halusinasi pendengaran. Pembahasan menyangkut analisis hasil penerapan terapi generalis terhadap masalah keperawatan halusinasi pendengaran. Tindakan keperawatan didasarkan pada pengkajian dan diagnosis keperawatan yang terdiri dari tindakan generalis yang dijabarkan sebagai berikut.

Tahap pengkajian pada klien halusinasi dilakukan interaksi perawat-klien melalui komunikasi terapeutik untuk mengumpulkan data dan informasi tentang status kesehatan klien. Pada tahap ini terjadi proses interaksi manusia, komunikasi, transaksi dengan peran yang ada pada perawat sebagaimana konsep tentang manusia yang bisa dipengaruhi dengan adanya proses interpersonal.

Selama pengkajian dilakukan pengumpulan data dari beberapa sumber, yaitu dari klien dan tenaga kesehatan di ruangan. Penulis mendapat sedikit kesulitan dalam menyimpulkan data karena keluarga klien jarang mengunjungi klien di rumah sakit jiwa. Maka penulis melakukan pendekatan kepada klien melalui komunikasi terapeutik yang lebih terbuka membantu klien untuk memecahkan perasaannya dan juga melakukan observasi kepada klien.

Adapun upaya tersebut yaitu: 
a. Melakukan pendekatan dan membina hubungan saling percaya diri pada klien agar klien lebih terbuka dan lebih percaya dengan menggunakan perasaan.

b. Mengadakan pengkajian klien dengan wawancara

c. Mengadakan pengkajian dengan cara membaca status, melihat buku rawatan dan bertanya kepada pegawai ruangan sorik merapi.

Dalam pengkajian ini,penulis menemukan kesenjangan karena ditemukan. Pada kasus Tn. M, klien mendengar suara-suara yang menyuruh untuk melakukan sholat, gelisah, mondar-mandir, tampak tegang, putus asa, sedih dan lain-lain.Gejala gejala yang muncul tersebut tidak semua mencakup dengan yang ada di teori klinis dari halusnasi (Keliat,.2014). Akan tetapi terdapat faktor predisposisi maupun presipitasi yang menyebabkan kekambuhan penyakit yang dialami oleh Tn.M

Tindakan keperawatan terapi generalis yang dilakukan pada Tn.M adalah strategi pertemuan pertama sampai pertemuan empat. Strategi pertemuan pertama meliputi mengidentifikasi isi, frekuensi, jenis, dan respon klien terhadap halusinasi serta melatih cara menghardik halusinasi. Strategi pertemuan kedua yang dilakukan pada Tn.M meliputi melatih cara mengendalikan dengan bercakap-cakap kepada orang lain. Strategi pertemuan yang ketiga adalah menyusun jadwal kegiatan bersama-sama dengan klien. Strategi pertemuan keempat adalah mengajarkan dan melatih Tn.Ecara minum obat yang teratur.

\subsection{Diagnosa Keperawatan}

Pada Teori Halusinasi (NANDA, 2015-2017), diagnosa keperawatan yang muncul sebanyak 3 diagnosa keperawatan (Aji, 2019) yang meliputi:

1. Gangguan Persepsi Sensori : Hausinasi Pendengaran

2. Isolasi Sosial

3. Gangguan Konsep Diri : Harga diri rendah 
Sedangkan pada kasus Tn. M ditemukan lima diagnosa keperawatan yang muncul yang meliputi: harga diri rendah, isolasi sosial, halusinasi, koping individu inefektif, regimen teraupetik inefektif. Dari hal tersebut di atas dapat dilihat terjadi kesamaan antara teori dan kasus. Dimana semua diagnosa pada teori muncul pada kasus Tn.M

\subsection{Implementasi}

Implementasi,adalah tahap dimana perawat memulai melakukan tindakan penulis hanyamengatasi masalah keperawatanhalusinasi pendengaran. Dengan melakukan strategi pertemuan yaitu mengidentifikasi isi, frekuensi, waktu terjadi, perasaan, respon halusinasi. Kemudian strategi pertemuan yang dilakukan yaitu latihan mengontrol halusinasi dengan cara menghardik. Strategi pertemuan yang kedua yaitu anjurkan minum obat secara teratur, strategi pertemuan yang ke tiga yaitu latihan dengan cara bercakap-cakap pada saat aktivitas dan latihan strategi pertemuan ke empat yaitu melatih klien melakukankegiatan terjadwal.

\subsection{Evaluasi}

Pada tinajauan teoritis evaluasi yang diharapkan adalah: Klien mempercayai perawat sebagai terapis, klien menyadari bahwa yang dialaminya tidak ada objeknya, dapat mengidentifikaasi halusinasi, dapat mengendalikan halusinasi melalui mengahrdik, latihan bercakap-cakap, melakukan aktivitas serta menggunakan obat secara teratur.

Pada tinjauan kasus evaluasi yang didapatkan adalah: Klien mampu mengontrol dan mengidentifikasi halusinasi, Klien mampu melakukan latihan bercakap-cakap dengan orang lain, Klien mampu melaksanakan jadwal yang telah dibuat bersama, Klien mampu memahami penggunaan obat yang benar: 5 benar. Selain itu, dapat dilihat dari setiap evalusi yang dilakukan pada asuhan keperawatan, dimana terjadi penurunan gejala yang dialami oleh Tn.M dari hari kehari selama proses interaksi.

\section{BAB 5}




\section{PENUTUP}

\subsection{Kesimpulan}

Kesimpulan Berdasarkan uraian pada pembahasan di atas, maka penulis dapat disimpulkan bahwa:

1. Pengkajian dilakukan secara langsung pada klien dan juga dengan menjadikan status klien sebagai sumber informasi yang dapat mendukung data-data pengkajian. Pada kasus Tn. M, diperoleh bahwa klien mengalami gejala-gejala halusinasi seperti mendengar suara-suara, gelisah, sulit tidur, mondar-mandir, sedih, malu, menarik diri, dan lainlain. Diagnosa keperawatan yang muncul pada kasus Tn. M, Halusinasi pendengaran, isolasi sosial, harga diri rendah. Tetapi pada pelaksanaannya, penulis fokus pada masalah utama yaitu halusinasi pendengaran.

2. Perencanaan dan implementasi keperawatan disesuaikan dengan strategi pertemuan pada pasien halusinasi pendengaran dan harga diri.

3. Evaluasi diperoleh bahwa terjadi peningkatan kemampuan klien dalam mengendalikan halusinasi yang dialami serta dampak pada penurunan gejala halusinasi pendengaran yang dialami.

\subsection{Saran}

1. Bagi pasien hendaknya dapat mengontrol emosi dengan menerapkan strategi pelaksanaan, mengidentifikasi isi, frekuensi, waktu terjadi, perasaan, respon halusinasi, latihan mengontrol halusinasi dengan cara menghardik, manjurkan minum obat secara teratur, latihan dengan cara bercakap-cakap pada saat aktivitas dan melatih klien melakukan semua jadwal kegiatan. 


\section{DAFTAR PUSTAKA}

1. Aritonang, M. (2021). Efektifitas Terapi Aktivitas Kelompok Stimulasi Terhadap Kemampuan Mengontrol Halusinasi Pendengaran Pada Pasien Ruang Cempaka Di Rsj Prof. Dr. M. Ildrem Medan Tahun 2019. Jurkessutra: Jurnal Kesehatan Surya Nusantara, 9(1).

2. Ana, F. (2019). Asuhan Keperawatan Jiwa Pada Klien Halusinasi Pendengaran Terintegrasi Dengan Keluarga Di Wilayah Kerja Puskesmas Lempake Samarinda (Doctoral dissertation, Poltekkes).http://repository.poltekkes-kaltim.ac.id/359/

3. Aji, W.M. H. (2019).Asuhan Keperawatan Orang Dengan Gangguan Jiwa Halusinasi Dengar Dalam Mengontrol Halusinasi.https://doi.org/10.31219/osf.io/n9dgs

4. Anggraini, T\& Maula, (2021). Asuhan Keperawatan Jiwa Pada An S Dengan Gangguan Persepsi Sensori Halusinasi Pendengaran. Karya Tulis Ilmiah, Universitas Kusuma Husada Surakarta.

5. Cressela, U. (2020). Asuhan Keperawatan Jiwa Dengan Gangguan Sensori Persepsi: Halusinasi Pendengaran Pada Kasus Skizofrenia Terhadap Ny. $R$ Di Ruang Melati Rs Jiwa Daerah Provinsi Lampung. Poltekkes Tanjungkarang .http://repository.poltekkestjk.ac.id/1988/

6. Damaiyanti \& Iskandar. (2014). Asuhan Keperawatan Jiwa. Bandung : Refika Aditama. http://repository2.unw.ac.id/id/eprint/102

7. Gasril, P., Suryani, S., \& Sasmita, H. (2020). Pengaruh Terapi Psikoreligious: Dzikir dalam Mengontrol Halusinasi Pendengaran Pada Pasien Skizofrenia yang Muslim di Rumah Sakit Jiwa Tampan Provinsi Riau. Jurnal Ilmiah Universitas Batanghari Jambi, 20(3), 821-826. http://dx.doi.org/10.33087/jiubj.v20i3.1063

8. Hernandi, B. (2020). Penerapan Aktivitas Terjadwal Pada Klien Dengan Gangguan Halusinasi Di Wilayah Kerja Puskesmas Godean 1 Skripsi, Poltekkes Kemenkes Yogyakart. $\underline{\text { http://eprints.poltekkesjogja.ac.id/id/eprint/2581 }}$

9. Jatinandya, M. P. (2020). Terapi Okupasi Pada Pasien Dengan Halusinasi Di Rumah Sakit Umum Daerah Banyumas. Jurnal Keperawatan Muhammadiya. http://dx.doi.org/10.30651/jkm.v0i0.5605

10. Keliat B,.(2014). Proses Keperawatan Jiwa Edisi II. Jakarta : EGC.

11. Keliat, Budu A. (2011). Keperawatan Kesehatan Jiwa Komunitas. EGC, Jakarta. 
12. Keliat, B.A \& Akemat. (2012). Model Praktik Keperawatan Profesional Jiwa. Jakarta:EGC.

13. Kemenkes RI. (2019). Riset Kesehatan Dasar, Riskesdas.Jakarta: Kemenkes

RI.https://databoks.katadata.co.id/datapublish/2019/10/08/persebaranprevalensi-skizofreniapsikosis-di-indonesia

14. Livana, P. H., Ruhimat, I. I. A., Sujarwoo, S., Suerni, T., Kandar, K., Maya, A., \& Nugroho, A. (2020). Peningkatan Kemampuan Klien dalam Mengontrol Halusinasi melalui Terapi Aktivitas Kelompok Stimulasi Persepsi. Jurnal Ners Widya Husada, 5(1), 35-40. https://doi.org/10.33666/jners.v5i1.328

15. Manao, B. M., \& Pardede, J. A. (2019). Beban Keluarga Berhubungan Dengan Pencegahan Kekambuhan Klien Skizofrenia. Jurnal Keperawatan Jiwa, 12(3).

16. Marsela, R., \& Dirdjo, M. M. (2016). Asuhan Keperawatan pada Ibu S yang Mengalami Gangguan Persepsi Sensori Halusinasi Pendengaran di Ruang Punai Rumah Sakit Jiwa Daerah Atma Husada Mahakam Samarinda. Karya Tulis Ilmiah Sekolah Tinggi Ilmu Kesehatan Muhammadiyah Samarinda. https://dspace.umkt.ac.id/handle/463.2017/1103?show=full

17. Mubarta, AF . (2011). Gambaran Distibusi Penderita Gangguan Jiwa di Wilaya Banjarmasin dan Banjarbaru. Tesis.http://dx.doi.org/10.33757/jik.v1i1.29

18. Mubin, M. F \&P. H. Livana. (2019). Hubungan Kepatuhan Minum Obat Dengan Kekambuhan Klien Skizofrenia Paranoid." Jurnal Farmasetis(8).1 https://doi.org/10.32583/farmasetis.v8i1.493

19. Nyumirah, S. (2013). Peningkatan kemampuan interaksi sosial (kognitif, afektif dan perilaku) melalui penerapan terapi perilaku kognitif di rsj dr amino gondohutomo semarang. Jurnal keperawatan jiwa, 1(2)..https://doi.org/10.26714/jkj.1.2.2013.\%25p

20. Oktiviani, D. P. (2020). Asuhan Keperawatan Jiwa Pada Tn. K dengan masalah Gangguan Persepsi Sensori: Halusinasi Pendengaran di Ruang Rokan Rumah Sakit Jiwa Tampan. Skripsi, Poltekkes Kemenkes Riau. http://repository.pkr.ac.id/id/eprint/498

21. Pardede, J. A., \& Hasibuan, E. K. (2019). Dukungan Caregiver Dengan Frekuensi Kekambuhan Klien Skizofrenia. Idea Nursing Journal, 10(2). http://e-repository.unsyiah.ac.id/INJ/article/view/17161 
22. Pardede, J. A., \& Laia, B. (2020). Decreasing Symptoms of Risk of Violent Behavior in Schizophrenia Patients Through Group Activity Therapy. Jurnal Ilmu Keperawatan Jiwa,3(3), 291-300 http://dx.doi.org/10.32584/jikj.v3i3.621

23. Pardede, J. A., Keliat, B. A., \& Yulia, I. (2015). Kepatuhan dan Komitmen Klien Skizofrenia Meningkat Setelah Diberikan Acceptance And Commitment Therapy dan Pendidikan Kesehatan Kepatuhan Minum Obat. Jurnal Keperawatan Indonesia, 18(3),157166.http://dx.doi.org/10.7454/jki.v18i3.419

24. Pardede, J. A., Irwan, F., Hulu, E. P., Manalu, L. W., Sitanggang, R., \& Waruwu, J. F. A. P. (2021). Asuhan keperawatan Jiwa Dengan Masalah Halusinasi. https://doi.org/10.31219/osf.io/fdqzn

25. Pardede, J. A., \& Siregar, R. A. (2016). Pendidikan Kesehatan Kepatuhan Minum Obat Terhadap Perubahan Gejala Halusinasi Pada Klienskizofrenia. Mental Health, 3(1).

26. Pratiwi, M., \& Setiawan, H. (2018). Tindakan Menghardik Untuk Mengatasi Halusinasi Pendengaran Pada Klien Skizofrenia Di Rumah Sakit Jiwa. Jurnal Kesehatan, 7(1), 7-13. http://dx.doi.org/10.46815/jkanwvol8.v7i1.76

27. Sari, J. R. (2019). Asuhan Keperawatan Jiwa dengan Gangguan Presepsi Sensori: Halusinasi Pendengaran pada kasus Sizofrenia terhadap Tn. A di Wilayah Kerja Puskesmas Kotabumi. Poltekkes Tanjung karang. http://repository.poltekkes-tjk.ac.id/1025/

28. Satria F. S.A \& Ice Y. W. (2019). Efektivitas Penerapan StandarAsuhan Keperawatan Jiwa Generalis Pada Klien Skizofrenia Dalam Menurunkan Gejala Halusinasi. http://jurnal.unimus.ac.id/index.php/JKJ/article/view/4855/pdf

29. Stuart, G. W. (2013). Buku Saku Keperawatan Jiwa . Edisi 5. Jakarta. EGC.

30. Townsend, M. C. (2014). Psychiatric Mental Healt Nursing : Concepts of Care in Evidence-BasedPractice(6thed.), Philadelphia: F.A. Davis.https://books.google.co.id/books?hl=id\&lr=\&id=3a0-

31. Yanti, D. A., Sitepu, A. L., Sitepu, K., \& Purba, W. N. B. (2020). Efektivitas Terapi Musik Klasik Terhadap Penurunan Tingkat Halusinasi Pada Pasien Halusinasi Pendengaran Di Rumah Sakit Jiwa Prof. Dr. M. Ildrem Medan Tahun 2020. Jurnal Keperawatan Dan Fisioterapi (Jkf), 3(1), 125-131. https://doi.org/10.35451/jkf.v3i1.527 
32. Yosep I. (2011). Keperawatan Jiwa (Edisi Revisi). Bandung: Refika Aditamahttp://repository.um-surabaya.ac.id/id/eprint/3356

33. Yusuf, A. (2015). Buku Ajar Keperawatan Kesehatan Jiwa.JakartaSalemba 